\title{
Meat quality of culled adult goats finished with increased feeding plans
}

\author{
Iolly Tábata Oliveira MARQUES ${ }^{1}$, Cesar Carneiro Linhares FERNANDES ${ }^{1}$ (D), Fábio Roger VASCONCELOS ${ }^{2}$, \\ Juliana Paula Martins ALVES ${ }^{1}$, Assis Rubens MONTENEGRO ${ }^{1}$, Caroline Pessoa da SILVA ${ }^{1}$, \\ Felipe Brener Bezerra de OLIVEIRA ${ }^{3}$, Francisco Cardoso FIGUEIREDO ${ }^{4}$, Arlindo Araripe MOURA 5 , \\ Davide RONDINA ${ }^{1 *}$
}

\begin{abstract}
This study evaluated the effect of increasing the nutritional plane in finishing diets on meat quality traits of culled adult goats. Forty-one crossbred does were divided into four groups: baseline diet formulated to meet $100 \%$ of the nutritional requirements (BD); $\mathrm{BD}+30 \%(\mathrm{BD} 30) ;+60 \%(\mathrm{BD} 60) ;+90 \%(\mathrm{BD} 90)$ of the nutritional level of $\mathrm{BD}$. The goats received the experimental diets for 28 days. The protein profile of the longissimus lumborum muscle was evaluated using 1D SDS-PAGE and mass spectrometry. Cholesterol and albumin concentrations were highest in the BD group. There were no alterations in loin proximate composition or tissue composition. However, there was a significant reduction in the PUFA content in groups BD60 and BD90 compared with the group fed the baseline diet. Of 37 protein bands identified, 35 showed lower intensities in group BD90 than in BD and 22 bands showed lesser expression in groups BD60 and BD90 than in BD. The multivariate model identified 14 band proteins involved in group-diet segregation. Therefore, increasing the nutrient supply for finishing goats did not have marked positive effects on carcass. A lower expression of these proteins can have a profound impact on the qualitative aspects of the meat product.
\end{abstract}

Keywords: goats; meat quality; finishing diet; protein expression.

Practical Application: High-energy diets interfere with structural and metabolic muscle proteome.

\section{Introduction}

Among the domestic species destined for meat production, there has been a considerable expansion in goat farming in recent years, as driven by the Chinese and Australian markets. According to data from the Food and Agriculture Organization of the United Nations, there was a $1.5 \%$ increase in production of the species in the year 2018, generating more than 83,079,226 t of goat meat (Food and Agriculture Organization, 2019). The proportion of females in the total number of slaughtered ruminants has increased in the last years as a result of the renewal of dairy herds, since the discarded animals are destined for slaughter and their meat sold. According to FAO data, 217 million of the approximately 633 million head of animals slaughtered in 2018 consisted of adult goats (Food and Agriculture Organization, 2020). Due to their low feed conversion efficiency, these animals require diets with a higher energy content to ensure heavier slaughter weights and better carcass quality (Assan, 2015). Thus, several studies have investigated the effect of increasing the energy density in nutritional and finishing planes for small ruminants and shown positive effects on weight gain in different breeds of goat and sheep (Aguayo-Ulloa et al., 2013).

Skeletal muscle quality is directly determined by the diet composition, since it induces changes in the main proteins that make up the contractile system, e.g., myosin, actin, troponin and tropomyosin. In ruminants, myoblasts are formed in the fetal period and undergo myofibrillar differentiation between the 4 th and 8th weeks after birth. However, as the body develops, the muscular structure does not undergo major changes, since adult individuals have higher levels of factors that inhibit cell division such as Sprouty 1, which inhibits fibroblast growth factor (FGF) signaling, besides exhibiting loss and/or aging of satellite cells (Sousa-Victor et al., 2015).

The study of the protein profile proves to be a more accurate strategy, as it provides a better understanding of the biological processes that determine the phenotypes as well as the explanation for and prediction of variations in meat quality (Picard et al., 2014). Of the molecular tools of expression, allows a correlation of protein abundance with meat quality (Lametsch \& Bendixen, 2001), indicating the expression of proteins that interfere with parameters such as tenderness, juiciness, flavor and color, which are considered the most important intrinsic traits in meat quality from a consumer perspective (Miller et al., 2001).

Research results show that there is a differential protein expression in the muscle in response to various events, e.g. increase in nicotinamide adenine dinucleotide dehydrogenase (NADH)

Received 02 June, 2021

Accepted 18 Oct., 2021

${ }^{1}$ Faculdade de Medicina Veterinária, Universidade Estadual do Ceará - UECE, Fortaleza, CE, Brasil

${ }^{2}$ Instituto Federal do Ceará, Campus Boa Viagem, Boa Viagem, CE, Brasil

${ }^{3}$ Instituto da Saúde e Produção Animal, Universidade Federal Rural da Amazônia - UFRA, Belém, PA, Brasil

${ }^{4}$ Departamento de Química, Laboratório de Análises de Combustíveis - LAPETRO, Universidade Federal do Piauí - UFPI, Teresina, PI, Brasil

${ }^{5}$ Departamento de Zootecnia, Universidade Federal do Ceará - UFC, Fortaleza, CE, Brasil

*Corresponding author: davide.rondina@uece.br 
and heat-shock protein 70 (HSP70) in the muscle protein postmortem, which alters myofibrillar stability (Bjarnadóttir et al., 2010); increased fragmentation of myosin light chain 1 (MYL1), troponin $\mathrm{C}$ and desmin, which help to predict meat tenderness (Zapata et al., 2009); as well as negative regulation of carbonic anhydrase 2 (CA2) and myosin light chain 3 (MYL3) during the deposition of intramuscular fat (Zhang et al., 2010). However, information is still lacking on changes in the meat protein profile of goat in response to dietary changes.

At the intracellular level, the increase in energy availability can lead to disturbances of homeostatic balance, triggering an inflammation in the endoplasmic reticulum, a sarcoplasmic organelle, in response to metabolic stress (Deldicque et al., 2010). This stress can induce defense mechanisms such as unfolded protein response (UPR) (Deldicque et al., 2010), whose action promotes changes in the formation of the tertiary and quaternary structure of proteins by altering the expression of chaperone proteins (Xu et al., 2005). These, in turn, can compromise muscle protein composition and, consequently, the quality of meat products.

Nevertheless, conflicting information is found in the literature regarding the diet effect on the meat composition of adult ruminants, since nutritional stimuli can no longer change the chemical composition of the meat once the animal body reaches maturity. Rather, these stimuli can improve carcass yield as a result of increased lipid deposition (Fruet et al., 2016). In goats, fat deposition occurs later, and prominently in the omental tissue through adipocyte hypertrophy with triglycerides, which are generated from the degradation of dietary carbohydrates and drained into the tissues by the hepatic portal system (Cianzio et al., 1985).

A large part of the existing studies in ruminants, especially in the goat species, are carried out with young animals, underestimating the importance of the production of meat from adult or cull animals, whose consumption is a market reality and a practice strongly associated with local food traditions.

In view of this dearth of information, research is warranted to clarify the impact of the nutritional supply on the molecular aspects of meat from adult animals. Thus, our objective was to examine, under experimental conditions, the effect of different finishing diets on the main organs; chemical and tissue composition and fatty acid profile of the loin; as well as the protein profile of the longissimus lumborum (LL) muscle of culled adult goats.

\section{Materials and methods}

The experiment was conducted at School of Veterinary of the Ceará State University - UECE, Brazil and all procedures used in this study were approved by the Ethics Committee in Animal Experimentation of UECE ( $n^{\circ} .12066667-7 / 18$, CEUA UECE). The present study represents an effort to investigate how diets influence adult animal meat quality, following a primary evaluation focused on effects on reproduction and proteome of oviduct and uterus of goats (Fernandes et al., 2018a, b).

\subsection{Animals and carcass samples}

The animals used in this experiment were 41 Anglo-Nubian crossbred nonpregnant and nonlactating goats with age of $2.8 \pm$
0.7 (overall mean \pm SD) years and live weight of $30.0 \pm 2.9 \mathrm{~kg}$. They were fed twice a day (07:00 and 15:00 hr) with a baseline diet (BD) composed of chopped Bermuda grass hay ( $11.1 \% \mathrm{CP})$, milled corn $(9.6 \% \mathrm{CP})$, wheat bran $(16.5 \% \mathrm{CP})$, and soybean meal $(43.9 \% \mathrm{CP})$. A BD was administrated during 28 days to four groups-treatments. Goats in Group BD $(\mathrm{n}=11)$ were fed with a BD to meet $100 \%$ of their nutritional requirements (National Research Council, 2007) and maintain live weight. In the other three groups diet was furnished in quantity to promote a weight gain providing respectively, $+30 \%($ Group $\mathrm{BD} 30 ; \mathrm{n}=10),+$ $60 \%$ (Group BD60; $\mathrm{n}=10),+90 \%$ (Group BD90; $\mathrm{n}=10$ ) than nutrient level of Group BD. Goats were kept in open shed pens modified to allow the control of individual intake during the feeding administration. Orts were collected daily and weighed to determine the intake and the extent of acceptance of the diet by the animals. Water and mineral salts were provided ad libitum to the animals.

After 4 weeks of feeding, the animals were weighed and then subjected to solid and liquid fasting for 16 hours and then were weighed again and slaughtered according to Brasil (1952). After skinning, evisceration and removal of the head and extremities, the anatomical components (the lungs, heart, spleen, liver, kidneys, pancreas, empty stomach, empty intestines, omentum adipose tissues) were weighed. The carcasses were then stored at $4{ }^{\circ} \mathrm{C}$ for $24 \mathrm{~h}$. Next, carcasses were then longitudinally cut into two halfcarcasses and the loin were collected from the left half-carcass, and then were identified, wrapped using parafilm and stored in a freezer at $-20^{\circ} \mathrm{C}$ for further tissue composition analyses.

For the longissimus lumborum (LL) proteomic analysis, fractions of approximately $10 \mathrm{~g}$ of the muscle were collected between the second and fourth lumbar vertebrae, around 10 minutes after slaughter of each animal, which were placed in sterile tubes, then frozen in liquid nitrogen and stored at $-80^{\circ}$ $\mathrm{C}$ until the subsequent analysis. The stored LL muscle samples were lyophilized for $24 \mathrm{~h}$, and then macerated to a very fine powder, which was stored in sterile tubes at $-20^{\circ} \mathrm{C}$ until the time of protein extraction.

Moreover, the loin (complete portion between the first and sixth lumbar vertebra) of all slaughtered goats were collected, identified, vacuum packed and stored in a freezer at $-20^{\circ} \mathrm{C}$ for further tissue composition analyses.

\subsection{Loin tissue dissection and proximate composition}

The complete loin was thawed inside plastic bags in a refrigerator at $10^{\circ} \mathrm{C}$ for $20 \mathrm{~h}$ for the tissue analyses according Oliveira et al. (2015). Briefly, the muscle, adipose and bone tissues were separated using a scalpel, knife and anatomical clamp. The muscle tissue consisted of all the muscles dissected after the complete removal of the attached subcutaneous and intermuscular fat. The adipose tissue consisted of the external (located below the skin) and the intermuscular (located below the deep fascia, associated with the muscle) fat. The bone tissue was obtained after the complete removal of all the attached muscle and fat. After the dissection, each tissue was weighed.

The proximate composition of the muscle was determined according to the Association of Official Analytical Chemists 
(1990), and the moisture was obtained by drying a sample in an oven at $105^{\circ} \mathrm{C}$ until it reached a constant weight. The nitrogen content was determined by the Kjeldahl method and converted to crude protein using a factor of 6.25 . The fixed mineral residue was determined by incineration at $550^{\circ} \mathrm{C}$. The total lipids were determined by a hot extraction process using an organic solvent (he xane) at $120^{\circ} \mathrm{C}$.

\subsection{Loin fatty acid composition}

The lipids were extracted from $10 \mathrm{~g}$ muscle of loin samples according Folch et al. (1957) method and the conversion to fatty acid methyl esters was performed according to Hartman \& Lago (1973).

The extracted lipids were directly analysed by chromatographic analysis using a Thermo Scientific ${ }^{\text {TM }}$ TRACE GC Ultra chromatograph coupled with a Thermo Scientific ${ }^{\mathrm{TM}}$ ISQ mass spectrometer equipped with a SP'-2560 fused Sigma-Aldrich silica capillary column ( $100 \mathrm{~m} \times 0.25 \mathrm{~mm} \times 0.2 \mu \mathrm{m}$ film thickness) with helium as the carrier gas, with flow rate $1 \mathrm{ml} \cdot \mathrm{min}^{-1}$. The temperature of the injector and ion source were programmed at $260^{\circ} \mathrm{C}$ and $270{ }^{\circ} \mathrm{C}$, respectively. The initial column temperature of $90^{\circ} \mathrm{C}$ was held for $1 \mathrm{~min}$ and warmed to $180^{\circ} \mathrm{C}$ at $4{ }^{\circ} \mathrm{C} / \mathrm{min}$, held for $1 \mathrm{~min}$, then warmed $3^{\circ} \mathrm{C} / \mathrm{min}$ to $220^{\circ} \mathrm{C}$ for $10 \mathrm{~min}$. A commercial standard mixture (ref. FAME mix 37, $10 \mathrm{mg} / \mathrm{mL}$ components from Supelco Inc., Bellefont, PA, USA) was used as internal standard for FA methyl esters quantification.

\subsection{Protein analysis of the longissimus lumborum muscle}

\section{Protein extraction}

For protein extraction, the procedure was made according to Sanchez et al. (2001), with adaptations. Briefly, 5 miligrams of lyophilized sample were put into a microtube and $100 \mu \mathrm{L}$ MiliQ water (Direct-Q, Millipore ${ }^{\circ}$ ) with $1 \%$ X-100 Triton and incubated for 1 hour at $4{ }^{\circ} \mathrm{C}$. After this time, $400 \mu \mathrm{l}$ of buffet $(7 \mathrm{M}$ urea, $2 \mathrm{M}$ thiourea, $4 \%$ CHAPS, $40 \mathrm{mM}$ DTT [ditiotreitol] - GE Healthcare) were added and subsequently sonicated on ice. Then, treated samples was centrifuged for $30 \mathrm{~min}$ at $5000 \mathrm{~g}$ at $4{ }^{\circ} \mathrm{C}$ and the supernatant was reserved. Proteins were then resuspended in ultrapure water and protein concentration was determined in triplicates according to Bradford's method (Bradford, 1976), using Eppendorf BioSpectrometer ${ }^{\bullet}$.

\section{D SDS-PAGE gel electrophoresis}

All the protein samples were adjusted to $50 \mu \mathrm{g} / \mu \mathrm{L}$ and mixed (1:1) with the sample buffer (1,5 M TRIS-HCL at $\mathrm{pH}$ $8.8,4 \%$ sodium dodecyl sulfate [SDS], $20 \%$ (v/v) glycerol, $0,2 \mathrm{M}$ dithiothreitol [DTT] and $0.02 \%$ bromophenol blue). Then, the samples were heated for 90 seconds at $100^{\circ} \mathrm{C}$ prior electrophoresis. The separation of the proteins were by sodium dodecyl sulfate polyacrylamide gel electrophoresis (SDS-PAGE) using a 12.5\% polyacrylamide gel (Amersham ECL, GE Healthcare ${ }^{\circ}$, USA) at $500 \mathrm{~V}, 90 \mathrm{~W}$ e $25 \mathrm{~mA} / \mathrm{gel}$, with $10 \mu \mathrm{L}$ of $225-12 \mathrm{kDa}$ molecular weight standart mix (GE Healthcare, Piscataway, NJ, USA). The gel was stained with Coomassie Brilliant Blue R-250 (GE
Healthcare ${ }^{\oplus}$, USA) for $12 \mathrm{~h}$, and destained ater several washes in a solution containing methanol and acetic acid (40\%:7\%). After destaining, the gel was scanned at $300 \mathrm{dpi}$ (ImageScanner III, GE Healthcare ${ }^{\circ}$ USA) and evaluated using QuantityOne ${ }^{\circ}$ Software, version 4.6.3 (Bio-rad, Rockville, MD, USA). The bands were identified and matched among the animals to determine of their molecular weights and intensity.

\section{Protein identification by electrospray ionization quadrupole time-of-flight (ESI-Q-ToF) mass spectrometry}

Thirty-seven bands obtained were excised from the gel, sliced into small pieces $\left(\sim 1 \mathrm{~mm}^{3}\right)$, and subjected to digestion by trypsin (De Lazari et al., 2019). Briefly, the bands were destained with $25 \mathrm{mM}$ ammonium bicarbonate ph 8.0 in $50 \%$ acetonitrile solution, dehydrated by acetonitrile for 5 minutes and denatured under $10 \mathrm{mM}$ DTT solution. Then the peptides were alkylated (iodoacetamide $50 \mathrm{mM}$ ) and digested with trypsin at $37^{\circ} \mathrm{C}$, were recovered after $18 \mathrm{~h}$, extracted in 5\% formic acid and 50\% acetonitrile and dried in Speed Vac concentrator. Then, the products of trypsin digestion were injected in a nanoAcquityTM system (Waters Corp., Milford, MA, USA), using an BEH300 C18 column $(100 \mu \mathrm{m} \times 100 \mathrm{~mm})$. And eluted at $600 \mu \mathrm{l} / \mathrm{min}$ with acetonitrile gradient (5-85\%) containing $0.1 \%$ formic acid. The liquid chromatography system was connected to a nanoelectrospray mass spectrometer source (SYNAPT HDMS system, Waters Corp., Milford, MA, USA). The mass spectrometer was operated in positive mode using a source temperature of $90^{\circ} \mathrm{C}$ and capillary voltage of $3.5 \mathrm{kV}$. The instrument was calibrated with fragments of the double protonated ion [Glu1]-fibrinopeptide $\mathrm{B}(\mathrm{m} / \mathrm{z} 785.84)$, and the Lock mass used during the acquisition was the intact ion. The LC-MS/MS procedure was performed according to the data-dependent acquisition (DDA) method, selecting MS/MS doubly or triply charged precursor ions. Ions were fragmented by collision-induced dissociation using argon as the collision gas and ramp collision energy that varied according to the charge state of the selected precursor ion. Data acquisition was performed at an $\mathrm{m} / \mathrm{z}$ range of $300-2100$ for the MS survey $(1 \mathrm{scan} / \mathrm{sec})$ and at an $\mathrm{m} / \mathrm{z}$ range of $50-2500$ for MS/MS. Data were collected with MassLynx 4.1 software and processed using the Protein Lynx Global Server 2.4 (Waters Corp.) and were converted to peak list text files (.pkl) for database searching. For peptides identification, MS/MS ion searches were performed through the MASCOT server (Matrix Science Inc., London, UK, v.2.6) to search the NCBIprot and SwissProt databases. Searches were made given there was maximum one missed trypsin cleavage, that peptides were monoisotopic (with $+1,+2$ and +3 charge) and using partially oxidized methionine residues and carbamidomethylated cysteine residues. However, candidate peptide IDs were only accepted if the $\mathrm{m} / \mathrm{z}$ values were observed within $0.1 \mathrm{Da}$ (typically less than $0.05 \mathrm{Da}$ ) of the theoretical mass of the candidate ID, as determined when manually reviewing MASCOT search results.

\section{Relationship proteins-meat quality and Gene Ontology}

Protein information obtained by MASCOT was analysed using the freely accessible UniProtKB databases for searching Gene Ontology (GO) terms associated with proteins in a proteomics 
results identification list. In addition, proteins were analyzed for possible effects on the physical chemical parameters of meat by bibliography research.

\section{Protein interaction network analysis}

Protein-protein interaction (PPI) networks were retrieved from STRING version 10.0 database, which consists of known and predicted protein interactions collected from direct (physical) and indirect (functional) associations. Such database quantitatively integrates interaction data from four sourcesgenomic context, high throughput experiments, coexpression and previous knowledge from research publications. Network analysis was only evaluated for proteins differently expressed between the diets tested. STRING software was set to show no more than 10 interactions and medium confidence. Pathways not described for Capra hircus were analysed for Bos taurus species.

\subsection{Blood sampling, metabolites and glutathione peroxidase assays}

Blood samples were taken at the beginning and end of the experimental feeding period by through jugular venipuncture using heparinized vacutainer tubes (Labor import, Wei Hai, China), which was always performed prior to the morning feeding. The blood samples were centrifuged at $600 \mathrm{~g}$ for $15 \mathrm{~min}$, and the plasma obtained was stored $-20{ }^{\circ} \mathrm{C}$ for subsequent quantification of the metabolites. Plasma concentrations of total protein, albumin, glucose and cholesterol were determined using an automated biochemical analyzer (Mindray BS 120, Mindray') with commercial kits (Bioclin', Quibasa - Minas Gerais, Brazil). The sensitivity of the assay kit was $0.043 \mathrm{~g} / \mathrm{dL}$ for protein, $0.327 \mathrm{~g} /$ $\mathrm{dL}$ for albumin, $1.31 \mathrm{mg} / \mathrm{dL}$ for glucose and $1.472 \mathrm{mg} / \mathrm{dL}$ for cholesterol. Glutathione peroxidase (GPx) were analyzed before the starving period using a semi-automated biochemical analyzer (Randox RX Monza TM, Randox Laboratories", Crumlin, UK), by commercial kits (Randox Laboratories', Crumlin, UK) with $75 \mathrm{U} / \mathrm{l}$ sensitivity.

\subsection{Statistical analysis}

\section{Anova and means comparisons}

Data were subjected to analysis of variance (ANOVA) using the GLM procedures (Statistica v. 13.4.0.14, TIBCO Software, Inc., Palo Alto, CA, USA). Diet treatment (BD, BD30, BD60, and BD90), Time length of diets supplementation (Time) and interaction Diet vs. Time were the main effects tested for the measurements of dry matter intake, weight gain and metabolites' plasma composition. For the parameters of anatomical records, tissue dissection, proximate composition and fatty acid concentration, factor used was the Diet treatment. For all parameters the polynomial contrasts to test linear and quadratic effects of increasing levels of diet were computed.

Data from intensity of protein gel band was transformed into $\log 10 \mathrm{x}$ and subjected to ANOVA using $\mathrm{R}$ program (R Core Team, 2018), with main effect the diet treatment.
Pairwise comparisons were performed by the Newman-Keuls test except for protein gel bands where means comparisons were performed using Tukey's multiple test.

\section{Multivariate analysis}

Protein bands intensities were also subjected to multivariate analysis using the mixOmics package of $\mathrm{R}$ program ( $\mathrm{R}$ Core Team, 2018) for principal component analysis (PCA) and partial least squares-discriminant analysis (PLS-DA). Variable importance in the projection (VIP) values obtained from supervised statistical PLS-DA was used to quantify the contribution of each variable in a PLS-DA model. According to the criteria of a VIP value $>1.0$ in the PLS-DA model (Gosselin et al., 2010).

\section{Results}

\subsection{In vivo performance and metabolites}

Table 1 shows the dry matter intake, live weight gain and plasma metabolite values measured during the experimental period. Dry matter intake increased quadratically with the feeding levels and differed between the treatment groups. Live weight gain was similar between groups BD60 and BD90 and higher in these animals when compared with groups $\mathrm{BD}$ and $\mathrm{BD} 30$.

Plasma glucose, total protein and glutathione peroxidase concentrations did not differ between the nutritional planes. The highest cholesterol and albumin values were found in the $\mathrm{BD}$ group. Cholesterol decreases the concentrations in a quadratic way in relation to the dietary levels of the diets.

\subsection{Anatomical records}

The weights of kidney and omental adipose tissue were highest in the animals of group BD90 (Table 2). Differences were also found for liver weight between groups BD and BD90, in favor of the latter, and for pancreas weight between the animals fed the baseline diet and groups BD60 and BD90.

\subsection{Loin tissue dissection, composition and fatty acid content}

No diet effect was observed for the proportions of muscle, fat, bone or connective tissues relative to total loin weight (Table 3). Accordingly, the proximate composition of the loin was similar between the treatment groups (Table 4). There was a significant decrease in the unsaturated fatty acid content in groups BD60 and BD90 compared with group BD, and PUFA/SFA, UFA/SFA ratios were also decreased quadratically.

\subsection{Meat protein profile}

The electrophoretic profile of the longissimus lumborum muscle revealed 37 bands in common among all tested animals. Identification of the bands excised from the gel by ESI-Q-ToF revealed 41 different proteins (Table 5).

The proteins were grouped according to gene ontology and their role in the qualitative traits of meat. Most proteins participate in biological processes associated with $32 \%$ metabolic processes, $40 \%$ muscle contraction, $40 \%$ regulation and $28 \%$ 
Table 1. Means and standard errors of dry matter intakes, weight gains, peripheral metabolites and glutathione peroxidase in adult goats fed during 28 days with distinct nutritional levels.

\begin{tabular}{|c|c|c|c|c|c|c|c|c|c|}
\hline \multirow{2}{*}{ Parameters } & \multicolumn{4}{|c|}{ Group } & \multicolumn{5}{|c|}{$p$ Value } \\
\hline & $\mathrm{BD}$ & BD30 & BD60 & BD90 & Diet & Time & D vs. T & Linear & Quadratic \\
\hline $\begin{array}{l}\text { Goats } \\
\text { exposed, n }\end{array}$ & 11 & 10 & 10 & 10 & & & & & \\
\hline \multicolumn{10}{|l|}{$\begin{array}{l}\text { In vivo } \\
\text { performance }\end{array}$} \\
\hline $\begin{array}{l}\text { DM intake, } \\
\text { g.kg / MW }\end{array}$ & $52.0 \pm 0.4 \mathrm{a}$ & $62.3 \pm 0.4 b$ & $65.9 \pm 0.5 c$ & $71.3 \pm 0.6 \mathrm{~d}$ & 0.01 & 0.01 & 0.01 & 0.01 & 0.01 \\
\hline $\begin{array}{l}\text { DM intake, } \\
\% \mathrm{BW}\end{array}$ & $2.2 \pm 0.02 \mathrm{a}$ & $2.6 \pm 0.02 b$ & $2.8 \pm 0.02 c$ & $3.0 \pm 0.03 \mathrm{~d}$ & 0.01 & 0.01 & 0.01 & 0.01 & 0.01 \\
\hline $\begin{array}{l}\text { Daily weight } \\
\text { gain, g.day }\end{array}$ & $1.9 \pm 19.7 \mathrm{a}$ & $51.1 \pm 16.6 \mathrm{~b}$ & $66.7 \pm 14.6 \mathrm{~b}$ & $104.3 \pm 20.9 b$ & 0.01 & 0.01 & 0.08 & 0.49 & 0.74 \\
\hline $\begin{array}{l}\text { Total weight } \\
\text { gain, kg }\end{array}$ & $0.0 \pm 0.4 a$ & $1.3 \pm 0.2 b$ & $1.7 \pm 0.4 b c$ & $2.7 \pm 0.4 c$ & 0.01 & - & - & 0.33 & 0.61 \\
\hline \multicolumn{10}{|l|}{ Metabolites } \\
\hline $\begin{array}{l}\text { Glucose, } \\
\text { mg.dl }\end{array}$ & $55.3 \pm 1.9$ & $58.5 \pm 2.4$ & $55.4 \pm 1.2$ & $53.3 \pm 3.0$ & 0.44 & 0.08 & 0.40 & 0.26 & 0.22 \\
\hline $\begin{array}{l}\text { Protein, } \\
\text { mg.dl }\end{array}$ & $7.3 \pm 0.3$ & $7.3 \pm 0.1$ & $6.9 \pm 0.3$ & $7.1 \pm 0.1$ & 0.39 & 0.05 & 0.98 & 0.32 & 0.28 \\
\hline $\begin{array}{l}\text { Albumin, } \\
\text { mg.dl }\end{array}$ & $3.5 \pm 0.1 \mathrm{a}$ & $3.1 \pm 0.1 \mathrm{~b}$ & $2.8 \pm 0.1 \mathrm{~b}$ & $2.4 \pm 0.1 \mathrm{c}$ & 0.01 & 0.85 & 0.05 & 0.53 & 0.97 \\
\hline $\begin{array}{l}\text { Cholesterol, } \\
\text { mg.dl }\end{array}$ & $75.4 \pm 3.5 \mathrm{a}$ & $61.8 \pm 3.5 b$ & $61.0 \pm 3.0 \mathrm{~b}$ & $60.7 \pm 2.1 \mathrm{~b}$ & 0.01 & 0.66 & 0.48 & 0.01 & 0.02 \\
\hline $\begin{array}{l}\text { Glutathione } \\
\text { peroxidase*, }^{*} \\
\text { U.L }^{-1}\end{array}$ & $105.6 \pm 21.2$ & $118.8 \pm 28.7$ & $129.5 \pm 32.3$ & $107.4 \pm 23.9$ & 0.91 & - & - & 0.73 & 0.73 \\
\hline
\end{tabular}

tissue development, most of them have a $40 \%$ molecular binding function and $36 \%$ catalytic activity, and as a cellular component, $44 \%$ participate in the cytoskeleton and $28 \%$ do cytosol. As regards the quality of the meat product, the most recorded functions were associated with physicochemical parameters such as $36 \%$ tenderness, $28 \%$ drip loss and $24 \%$ fat deposition.

The Figure 1 shows the SDS-PAGE 1D gels, which shows the electrophoretic profile of LL of goats muscle proteins. In Figure 2 was given the results of the comparison between diets for band intensity. Except for bands 3 (MYH1 and MYH4 proteins) and 35 (TNNC1 and PPIA proteins), all 35 protein bands were affected by the nutritional treatment (Figure 2). Apparently, the intensity of the bands decreased as the feeding level was increased. For 22 bands, a lower expression was detected in groups BD60 and BD90 than in groups BD and BD30, whereas for 35 bands lesser expression was seen in group BD90 compared with groups $\mathrm{BD}$ and $\mathrm{BD} 30$.

\subsection{Multivariate analysis}

Figure 3 shows the score plot for the results of multivariate analysis performed in the protein bands. The diets groups were colored green (BD), black (BD30), blue (BD60) and red (BD90). The first, second and third principal components of the multivariate model retained $71 \%$, $10 \%$ and $5 \%$ of the total variance, respectively, accounting for $86 \%$ of the cumulative variance together. The prediction model generated with PLS-DA showed accuracy measures of the area under the curve (AUC) of $96.3 \%, 96.3 \%, 100 \%$ and $98.1 \%$ for treatments BD, BD30, BD60 and BD90 $(\mathrm{P}<0.01)$, respectively.

The 14 identified protein bands with variable importance (VIP) scores > 1.0 (Gosselin et al., 2010) in the multivariate model were grouped in Figure 4, corresponding to $37.84 \%$ of the total bands. Seven of these VIP group are part of structural contractile muscle complex: Myosin light chain 1/3 skeletal muscle (MYL1, bands 36, 32, and 31), Myosin light regulatory chain 2, (MYLPF, band 34), Myosin heavy chain (MYH, bands 1, 2, 3, 6), Desmin (DES, band 14), Alpha-actinin-3 (ACTN3, band 2), Fast skeletal troponin I (TNNI2, band 31), Tropomyosin (TPM, bands 37, 24 and 19), one is involved with oxygen transport, Hemoglobin subunit beta-A ( $\mathrm{HBB}$, band 37), another protein belonging to the lysosome involved in lipid degradation, the Peroxiredoxin-6 (PRDX6, band 27) and seven are relationship with energetic metabolism, glycolytic pathway and citric acid cycle: ATP synthase subunit beta and Dihydrolipoyllysine-residue succinyltransferase component of 2-oxoglutarate dehydrogenase complex (ATP5F1B and DLST, band 15), Fructose-bisphosphate aldolase A and Glyceraldehyde-3-phosphate dehydrogenase (ALDOA and GAPDH, band 19), Pyruvate kinase (PMK, band 14), Phosphoglycerate mutase 2 (PGAM2, band 27) and Glycogen phosphorylase, muscle form (PYGM, band 6). In the VIP bands, 16 proteins were not repeated between the bands, about $21.92 \%$ of the total proteins reported in Table 5. 
Original Article

Meat quality in finishing adult goats

Table 2. Means and standard errors of anatomical records performed at slaughter in adult goats fed during 28 days with distinct nutritional levels.

\begin{tabular}{|c|c|c|c|c|c|c|c|}
\hline \multirow[t]{2}{*}{ Parameters } & \multicolumn{4}{|c|}{ Group } & \multicolumn{3}{|c|}{$p$ Value } \\
\hline & $\mathrm{BD}$ & BD30 & BD60 & BD90 & Diet & Linear & Quadratic \\
\hline $\mathrm{FW}^{*}, \mathrm{~kg}$ & $29.3 \pm 1.2$ & $29.5 \pm 1.0$ & $28.8 \pm 0.8$ & $31.3 \pm 1.0$ & 0.35 & 0.40 & 0.35 \\
\hline Heart, g & $129.1 \pm 7.3$ & $133.0 \pm 8.2$ & $127.0 \pm 8.9$ & $145.0 \pm 4.8$ & 0.33 & 0.92 & 0.80 \\
\hline Lungs, $g$ & $260.9 \pm 13.4$ & $272.0 \pm 17.5$ & $231.0 \pm 16.0$ & $235.0 \pm 11.1$ & 0.16 & 0.92 & 0.80 \\
\hline Liver, $g$ & $434.5 \pm 26.6 \mathrm{a}$ & $471.0 \pm 24.9 \mathrm{ab}$ & $482.0 \pm 27.5 \mathrm{ab}$ & $544.0 \pm 14.7 \mathrm{~b}$ & 0.02 & 0.81 & 0.60 \\
\hline Spleen, $g$ & $53.6 \pm 3.9$ & $58.0 \pm 7.8$ & $51.0 \pm 2.8$ & $60.0 \pm 2.6$ & 0.53 & 0.67 & 0.63 \\
\hline Pancreas, $g$ & $36.4 \pm 4.9 \mathrm{a}$ & $49.0 \pm 5.7 \mathrm{ab}$ & $56.0 \pm 4.3 \mathrm{~b}$ & $61.0 \pm 4.6 \mathrm{~b}$ & 0.01 & 0.26 & 0.43 \\
\hline Kidneys, g & $73.6 \pm 4.3 \mathrm{a}$ & $77.0 \pm 3.3 \mathrm{a}$ & $78.0 \pm 3.3 \mathrm{a}$ & $91.0 \pm 3.5 b$ & 0.01 & 0.32 & 0.19 \\
\hline $\mathrm{OAT}^{\star *}, \mathrm{~g}$ & $503.6 \pm 82.1 \mathrm{a}$ & $531.0 \pm 74.9 \mathrm{a}$ & $623.0 \pm 74.9 \mathrm{a}$ & $898.0 \pm 107.6 b$ & 0.01 & 0.26 & 0.15 \\
\hline $\begin{array}{l}\text { Empty Stomachs, } \\
\text { kg }\end{array}$ & $5.7 \pm 0.3$ & $6.1 \pm 0.3$ & $5.5 \pm 0.4$ & $5.3 \pm 0.3$ & 0.33 & 0.42 & 0.35 \\
\hline $\begin{array}{l}\text { Empty Intestines, } \\
\mathrm{kg}\end{array}$ & $2.1 \pm 0.1$ & $2.3 \pm 0.1$ & $2.2 \pm 0.1$ & $2.2 \pm 0.2$ & 0.68 & 0.36 & 0.38 \\
\hline \multicolumn{8}{|l|}{$\begin{array}{l}\text { Weights as \% of } \\
\text { FW }\end{array}$} \\
\hline Heart, \% & $0.44 \pm 0.01$ & $0.45 \pm 0.02$ & $0.44 \pm 0.03$ & $0.46 \pm 0.01$ & 0.81 & 0.78 & 0.73 \\
\hline Lungs, \% & $0.90 \pm 0.04$ & $0.92 \pm 0.05$ & $0.80 \pm 0.05$ & $0.75 \pm 0.02$ & 0.05 & 0.50 & 0.35 \\
\hline Liver, \% & $1.48 \pm 0.05 a$ & $1.60 \pm 0.07 \mathrm{ab}$ & $1.67 \pm 0.08 \mathrm{ab}$ & $1.74 \pm 0.04 \mathrm{~b}$ & 0.03 & 0.50 & 0.69 \\
\hline Spleen, \% & $0.18 \pm 0.01$ & $0.20 \pm 0.03$ & $0.18 \pm 0.01$ & $0.19 \pm 0.01$ & 0.78 & 0.86 & 0.87 \\
\hline Pancreas, \% & $0.12 \pm 0.01 \mathrm{a}$ & $0.17 \pm 0.02 \mathrm{ab}$ & $0.19 \pm 0.01 b$ & $0.19 \pm 0.01 b$ & 0.01 & 0.12 & 0.20 \\
\hline Kidneys, \% & $0.25 \pm 0.01 \mathrm{a}$ & $0.26 \pm 0.01 \mathrm{ab}$ & $0.27 \pm 0.01 \mathrm{ab}$ & $0.29 \pm 0.01 b$ & 0.05 & 0.87 & 0.68 \\
\hline OAT, $\%$ & $1.65 \pm 0.2 \mathrm{a}$ & $1.78 \pm 0.2 \mathrm{a}$ & $2.1 \pm 0.2 \mathrm{a}$ & $2.8 \pm 0.3 b$ & 0.01 & 0.39 & 0.23 \\
\hline $\begin{array}{l}\text { Empty Stomachs, } \\
\%\end{array}$ & $19.6 \pm 0.7 \mathrm{ab}$ & $20.8 \pm 0.8 \mathrm{a}$ & $18.9 \pm 1.2 \mathrm{ab}$ & $16.8 \pm 0.8 b$ & 0.01 & 0.09 & 0.05 \\
\hline $\begin{array}{l}\text { Empty Intestines, } \\
\%\end{array}$ & $7.06 \pm 0.37$ & $7.9 \pm 0.45$ & $7.6 \pm 0.40$ & $6.9 \pm 0.3$ & 0.26 & 0.05 & 0.06 \\
\hline
\end{tabular}

Table 3. Means and standard errors of loin tissue dissection of adult goats fed during 28 days with distinct nutritional levels.

\begin{tabular}{|c|c|c|c|c|c|c|c|}
\hline \multirow{2}{*}{ Parameters } & \multicolumn{4}{|c|}{ Group } & \multicolumn{3}{|c|}{$p$ Value } \\
\hline & $\mathrm{BD}$ & BD30 & BD60 & BD90 & Diet & Linear & Quadratic \\
\hline Loin,g & $148.2 \pm 8.8 \mathrm{a}$ & $126.5 \pm 7.7 \mathrm{ab}$ & $111.1 \pm 7.9 \mathrm{~b}$ & $130.7 \pm 7.4 \mathrm{ab}$ & 0.02 & 0.05 & 0.06 \\
\hline \multicolumn{8}{|l|}{ Dissection, $g$} \\
\hline Adipose & $8.3 \pm 2.1$ & $7.2 \pm 1.3$ & $4.3 \pm 0.7$ & $4.4 \pm 0.8$ & 0.08 & 0.50 & 0.66 \\
\hline Bone & $32.0 \pm 1.7$ & $29.3 \pm 2.6$ & $27.4 \pm 1.9$ & $26.7 \pm 1.7$ & 0.27 & 0.51 & 0.63 \\
\hline \multicolumn{8}{|l|}{ Weights as \% LW* } \\
\hline Muscle, $\%$ & $47.1 \pm 1.9$ & $45.0 \pm 1.7$ & $44.4 \pm 2.3$ & $50.8 \pm 1.8$ & 0.10 & 0.05 & 0.06 \\
\hline Adipose, $\%$ & $5.5 \pm 1.4$ & $6.9 \pm 1.3$ & $3.8 \pm 0.6$ & $3.2 \pm 0.5$ & 0.21 & 0.73 & 0.60 \\
\hline Bone, \% & $21.9 \pm 1.2$ & $23.0 \pm 1.1$ & $25.4 \pm 2.0$ & $20.5 \pm 1.0$ & 0.10 & 0.05 & 0.06 \\
\hline Connective, $\%$ & $15.2 \pm 0.9$ & $15.9 \pm 1.0$ & $15.8 \pm 1.0$ & $14.0 \pm 0.9$ & 0.40 & 0.21 & 0.18 \\
\hline
\end{tabular}

${ }^{*}$ Loin weight. Diets $=$ effect of diets. Contrast: Linear $=$ linear effect of increasing level of diets; Quadratic $=$ quadratic effect of increasing levels of diet.

For the analysis of the protein network, some of these were evaluated considering their expression pattern between groups as well as their relationship to the dietary treatments, energy metabolism and muscle function, in addition to their contribution to discrimination by the VIP multivariate model. According to this analysis, the MYL1 (band 36, Figure 5A), MYH1 (band 1,
Figure 5B) and TPM2 (band 37, Figure 5C) proteins showed interactions with a group of other proteins related to structural function and muscle contraction (such as troponin and actinmyosin complex proteins) and GAPDH (band 19, Figure 5D) shows interaction with a protein set present in the energy generation and cellular respiration pathways. 
Original Article

Marques et al.

Table 4. Means and standard errors of proximate composition and fatty acid concentration of the loin from adult goats fed during 28 days with distinct nutritional levels.

\begin{tabular}{|c|c|c|c|c|c|c|c|}
\hline \multirow{2}{*}{ Parameters } & \multicolumn{4}{|c|}{ Group } & \multicolumn{3}{|c|}{$p$ Value } \\
\hline & $\mathrm{BD}$ & BD30 & BD60 & BD90 & Diet & Linear & Quadratic \\
\hline \multicolumn{8}{|l|}{ Composition, \% } \\
\hline Moisture & $75.2 \pm 0.2$ & $75.6 \pm 0.5$ & $75.8 \pm 0.3$ & $75.2 \pm 0.3$ & 0.54 & 0.17 & 0.17 \\
\hline Protein & $13.0 \pm 1.0$ & $15.2 \pm 0.4$ & $13.1 \pm 0.9$ & $13.9 \pm 1.1$ & 0.41 & 0.35 & 0.36 \\
\hline Ash & $1.1 \pm 0.05$ & $1.1 \pm 0.01$ & $1.1 \pm 0.06$ & $1.3 \pm 0.09$ & 0.16 & 0.43 & 0.33 \\
\hline Total lipids & $7.7 \pm 0.7$ & $10.0 \pm 1.8$ & $7.2 \pm 1.0$ & $7.8 \pm 1.1$ & 0.40 & 0.64 & 0.64 \\
\hline \multicolumn{8}{|l|}{ Fatty acids, \% } \\
\hline SFA & $40.4 \pm 3.5 \mathrm{a}$ & $47.4 \pm 2.2 \mathrm{ab}$ & $61.1 \pm 5.2 b$ & $53.0 \pm 5.4 \mathrm{ab}$ & 0.01 & 0.05 & 0.09 \\
\hline UFA & $59.7 \pm 3.5 \mathrm{a}$ & $52.6 \pm 2.2 \mathrm{ab}$ & $38.3 \pm 5.1 b$ & $44.8 \pm 5.6 \mathrm{~b}$ & 0.01 & 0.07 & 0.13 \\
\hline MUFA & $3.8 \pm 1.2$ & $2.8 \pm 1.2$ & $3.6 \pm 0.3$ & $4.0 \pm 1.3$ & 0.11 & 0.05 & 0.05 \\
\hline PUFA & $55.9 \pm 3.3 \mathrm{a}$ & $49.7 \pm 2.8 \mathrm{ab}$ & $37.7 \pm 4.9 \mathrm{~b}$ & $40.7 \pm 5.2 b$ & 0.01 & 0.17 & 0.28 \\
\hline UFA/SFA & $1.6 \pm 0.2 \mathrm{a}$ & $1.1 \pm 0.1 \mathrm{ab}$ & $0.7 \pm 0.1 b$ & $1.0 \pm 0.2 \mathrm{ab}$ & 0.01 & 0.02 & 0.03 \\
\hline PUFA/SFA & $1.5 \pm 0.2 \mathrm{a}$ & 1.1. $\pm 0.1 \mathrm{ab}$ & $0.7 \pm 0.1 \mathrm{~b}$ & $0.9 \pm 0.2 b$ & 0.01 & 0.03 & 0.03 \\
\hline
\end{tabular}

SFA: saturated fatty acids; UFA: unsaturated fatty acids; MUFA: monounsaturated fatty acids; PUFA: polyunsaturated fatty acids. Diets = effect of diets. Contrast: Linear = linear effect of increasing level of diets; Quadratic = quadratic effect of increasing levels of diet.

Table 5. Proteins of the longissimus lumborum from adult goats fed during 28 days with distinct nutritional levels. Proteins were separated by one-dimensional SDS-PAGE and identified by tandem mass spectrometry (ESI-Q-ToF).

\begin{tabular}{|c|c|c|c|c|c|c|}
\hline Band & Protein name & Gene & $\begin{array}{c}\text { NCBI or SwissProt accession } \\
\text { nunber }\end{array}$ & $\begin{array}{c}\text { MS/MS } \\
\text { Protein } \\
\text { score }\end{array}$ & $\begin{array}{c}\text { Sequence } \\
\text { coverage } \\
(\%)\end{array}$ & $\begin{array}{l}\text { Number of } \\
\text { peptides }\end{array}$ \\
\hline 1 & Myosin-1 isoform X1 & MYH1 & XP_017920146.1 ${ }^{\mathrm{a}}$ & 938 & 9 & 15 \\
\hline 2 & Alpha-actinin-3 isoform $\mathrm{X} 1$ & ACTN3 & XP_017898846.1 a & 1131 & 20 & 16 \\
\hline 3 & Myosin-1 isoform X1 & MYH1 & XP_017920146.1 a & 2261 & 22 & 33 \\
\hline 4 & Myosin-binding protein $\mathrm{C}$, fast-type & MYBPC2 & XP_017918332.1 a & 221 & 3 & 3 \\
\hline 5 & Myosin-binding protein. slow-type isoform X5 & MYBPC1 & XP_005680574.1 a & 291 & 4 & 4 \\
\hline \multirow[t]{2}{*}{6} & Myosin-2 & MYH2 & XP_017920148.1 a & 978 & 9 & 17 \\
\hline & Glycogen phosphorylase, muscle form & PYGM & PYGM_BOVIN ${ }^{\mathrm{b}}$ & 139 & 2 & 2 \\
\hline 7 & Myosin-2 & MYH2 & XP_017920148.1 a & 1104 & 10 & 17 \\
\hline \multirow[t]{4}{*}{10} & Albumin precursor. Partial & ALB & ACF10391.1 $1^{\mathrm{b}}$ & 565 & 12 & 9 \\
\hline & Serum albumin & ALB & XP_005681801.1 a & 565 & 12 & 9 \\
\hline & Heat shock protein 70.1 & HSP70.1 & AEM24982.1 $1^{\mathrm{b}}$ & 441 & 14 & 6 \\
\hline & $\begin{array}{l}\text { Glycerol-3-phosphate dehydrogenase, } \\
\text { mitochondrial }\end{array}$ & GPD2 & GPDM_BOVIN $^{\mathrm{b}}$ & 74 & 2 & 1 \\
\hline 11 & No indetificate protein & & & & & \\
\hline 12 & Pyruvate kinase PKM isoform X2 & PKM & XP_005685234.1 a & 1000 & 34 & 17 \\
\hline \multirow[t]{2}{*}{13} & Pyruvate kinase PKM isoform X2 & PKM & XP_005685234.1 a & 1000 & 22 & 9 \\
\hline & Glucose-6-phosphate isomerase & GPI & XP_017917783.1 a & 298 & 10 & 4 \\
\hline 14 & Pyruvate kinase PKM isoform X2 & PMK & XP_005685234.1 a & 217 & 10 & 3 \\
\hline
\end{tabular}

${ }^{a}$ NCBIprot database (v. 20180429 with 152462470 sequences; 55858910152 residues) and b'SwissProt database (v. 2019_01 with 559077 sequences; 200828568 residues) 
Table 5. Continued...

\begin{tabular}{|c|c|c|c|c|c|c|}
\hline Band & Protein name & Gene & $\begin{array}{c}\text { NCBI or SwissProt accession } \\
\text { nunber }\end{array}$ & $\begin{array}{c}\text { MS/MS } \\
\text { Protein } \\
\text { score }\end{array}$ & $\begin{array}{c}\text { Sequence } \\
\text { coverage } \\
(\%)\end{array}$ & $\begin{array}{l}\text { Number of } \\
\text { peptides }\end{array}$ \\
\hline & $\begin{array}{l}\text { Pyruvate dehydrogenase E1 component subunit } \\
\text { alpha, mitochondrial }\end{array}$ & PDHA1 & ODPA_BOVIN ${ }^{\mathrm{b}}$ & 59 & 3 & 1 \\
\hline 17 & Beta actin, partial & ACTB & AAS68014.1 $1^{\mathrm{a}}$ & 48 & 80 & 2 \\
\hline \multirow[t]{2}{*}{18} & Fructose-bisphosphate aldolase $\mathrm{A}$ isoform $\mathrm{X} 1$ & ALDOA & XP_005697728.1 a & 304 & 16 & 4 \\
\hline & Creatine kinase M-type & CMK & XP_005692693.1 a & 732 & 32 & 35 \\
\hline \multirow[t]{3}{*}{19} & Fructose-bisphosphate aldolase A isoform X1 & ALDOA & XP_005697728.1 a & 770 & 38 & 21 \\
\hline & Tropomyosin alpha-1 chain & TPM1 & TPM1_BOVIN $^{\mathrm{b}}$ & 153 & 8 & 2 \\
\hline & Glyceraldehyde-3-phosphate dehydrogenase & GAPDH & G3P_BOVIN ${ }^{b}$ & 63 & 4 & 1 \\
\hline \multirow[t]{2}{*}{20} & Glyceraldehyde-3-phosphate dehydrogenase & GAPDH & G3P_BOVIN b & 403 & 25 & 5 \\
\hline & Fast skeletal muscle troponin $\mathrm{T}$ & TNNT3 & AEP14536.1 b & 347 & 22 & 5 \\
\hline \multirow[t]{2}{*}{21} & Glyceraldehyde-3-phosphate dehydrogenase & GAPDH & G3P_BOVIN ${ }^{\mathrm{b}}$ & 562 & 36 & 30 \\
\hline & Tropomyosin beta chain & TPM2 & TPM2_BOVIN $^{\mathrm{b}}$ & 336 & 30 & 10 \\
\hline \multirow[t]{3}{*}{22} & Fructose-bisphosphate aldolase A isoform X1 & ALDOA & XP_005697728.1 a & 534 & 30 & 9 \\
\hline & Tropomyosin beta chain & ТРМ2 & TPM2_BOVIN ${ }^{b}$ & 393 & 24 & 8 \\
\hline & Glyceraldehyde-3-phosphate dehydrogenase & GAPDH & G3P_BOVIN ${ }^{\mathrm{b}}$ & 231 & 34 & 5 \\
\hline \multirow[t]{3}{*}{23} & Tropomyosin alpha-1 chain & TPM1 & TPM1_BOVIN $^{\mathrm{b}}$ & 863 & 24 & 10 \\
\hline & Malate dehydrogenase, mitochondrial & $\mathrm{MDH} 2$ & MDHM_BOVIN ${ }^{\mathrm{b}}$ & 261 & 14 & 4 \\
\hline & Glyceraldehyde-3-phosphate dehydrogenase & GAPDH & G3P_BOVIN ${ }^{b}$ & 151 & 8 & 1 \\
\hline 24 & Tropomyosin alpha-1 chain & TPM2 & TPM2_BOVIN ${ }^{\mathrm{b}}$ & 876 & 23 & 11 \\
\hline \multirow[t]{5}{*}{25} & Lactate dehydrogenase & LDHC & NP_001272647.1 a & 286 & 13 & 4 \\
\hline & Malate dehydrogenase, mitochondrial & $\mathrm{MDH} 2$ & MDHM_BOVIN ${ }^{\mathrm{b}}$ & 203 & 16 & 4 \\
\hline & LIM domain-binding protein 3 isoform $\mathrm{X} 2$ & LDB3 & XP_017897677.1 a & 391 & 9 & 5 \\
\hline & Myozenin-1 & MYOZ1 & MYOZ1_BOVIN ${ }^{\mathrm{b}}$ & 181 & 8 & 2 \\
\hline & Beta-enolase & ENO3 & ENOB_BOVIN ${ }^{\mathrm{b}}$ & 85 & 3 & 1 \\
\hline \multirow[t]{2}{*}{26} & Keratin, type I cytoskeletal 10 isoform X1 & KRT10 & XP_017920532.1 a & 156 & 5 & 2 \\
\hline & NADH dehydrogenase [ubiquinone] & NDUFS3 & NDUS3_BOVIN ${ }^{b}$ & 93 & 9 & 2 \\
\hline \multirow[t]{2}{*}{27} & Phosphoglycerate mutase 2 & PGAM2 & XP_005695544.1 a & 474 & 40 & 8 \\
\hline & Peroxiredoxin-6 & PRDX6 & PRDX6_BOVIN ${ }^{\mathrm{b}}$ & 103 & 13 & 3 \\
\hline \multirow[t]{3}{*}{28} & Triosephosphate isomerase & TPI1 & XP_017904037.1 a & 740 & 36 & 10 \\
\hline & Phospholgycerate mutase 2 & PGAM2 & PGAM2_BOVIN ${ }^{\mathrm{b}}$ & 167 & 24 & 4 \\
\hline & Glutathione S-transferase Mu 1 & GSTM1 & GSTM1_BOVIN ${ }^{\mathrm{b}}$ & 89 & 5 & 1 \\
\hline \multirow[t]{2}{*}{29} & Myosin light chain $1 / 3$ skeletal muscle isoform X1 & MYL1 & XP_005676539.1 a & 534 & 48 & 9 \\
\hline & Myosin light chain 6B & MYL6B & XP_005680423.1 a & 275 & 31 & 4 \\
\hline 30 & Myosin light chain $1 / 3$ skeletal muscle isoform X1 & MYL1 & XP_005676539.1 a & 841 & 64 & 19 \\
\hline \multirow[t]{2}{*}{31} & Myosin light chain $1 / 3$ skeletal muscle isoform X1 & MYL1 & XP_005676539.1 a & 458 & 40 & 4 \\
\hline & Fast skeletal troponin I isoform. partial & TNNI2 & AAK56403.1 b & 244 & 31 & 4 \\
\hline 32 & Myosin lignt chain 2 & MYL2 & AJP08204.1 $1^{\mathrm{a}}$ & 365 & 34 & 7 \\
\hline \multirow[t]{2}{*}{33} & Myosin regulatory lignt chain 2 , skeletal muscle & MYLPF & NP_001272683.1 a & 599 & 62 & 4 \\
\hline & Tropomyosin alpha-1 & TPM1 & TPM1_BOVIN $^{\mathrm{b}}$ & 58 & 3 & 1 \\
\hline \multirow[t]{3}{*}{34} & Myosin light regulatory chain 2, skeletal muscle & MYLPF & NP_001272683.1 $1^{\mathrm{a}}$ & 864 & 79 & 16 \\
\hline & Myosin light chain $1 / 3$ skeletal muscle & MYL1 & XP_005676539.1 $1^{\mathrm{a}}$ & 85 & 5 & 1 \\
\hline & Tropomyosin alpha-1 & TPM1 & TPM1_BOVIN b & 141 & 3 & 2 \\
\hline \multirow[t]{2}{*}{35} & Troponin C, slow skeletal and cardiac muscles & TNNC1 & TNNC1_BOVIN ${ }^{\mathrm{b}}$ & 90 & 15 & 3 \\
\hline & Peptidyl-prolyl cis-trans isomerase A & PPIA & PPIA_BOVIN ${ }^{b}$ & 71 & 10 & 1 \\
\hline 36 & Myosin light chain $1 / 3$ skeletal muscle isoform X1 & MYL1 & XP_005676539.1 a & 539 & 37 & 10 \\
\hline \multirow[t]{2}{*}{37} & Hemoglobin subunit beta-A & HBB & HBBA_CAPHI ${ }^{b}$ & 69 & 7 & 1 \\
\hline & Tropomyosin beta chain & TPM2 & TPM2_BOVIN $^{\mathrm{b}}$ & 91 & 8 & 2 \\
\hline
\end{tabular}

${ }^{2}$ NCBIprot database (v. 20180429 with 152462470 sequences; 55858910152 residues) and bSwissProt database (v. 2019_01 with 559077 sequences; 200828568 residues) 


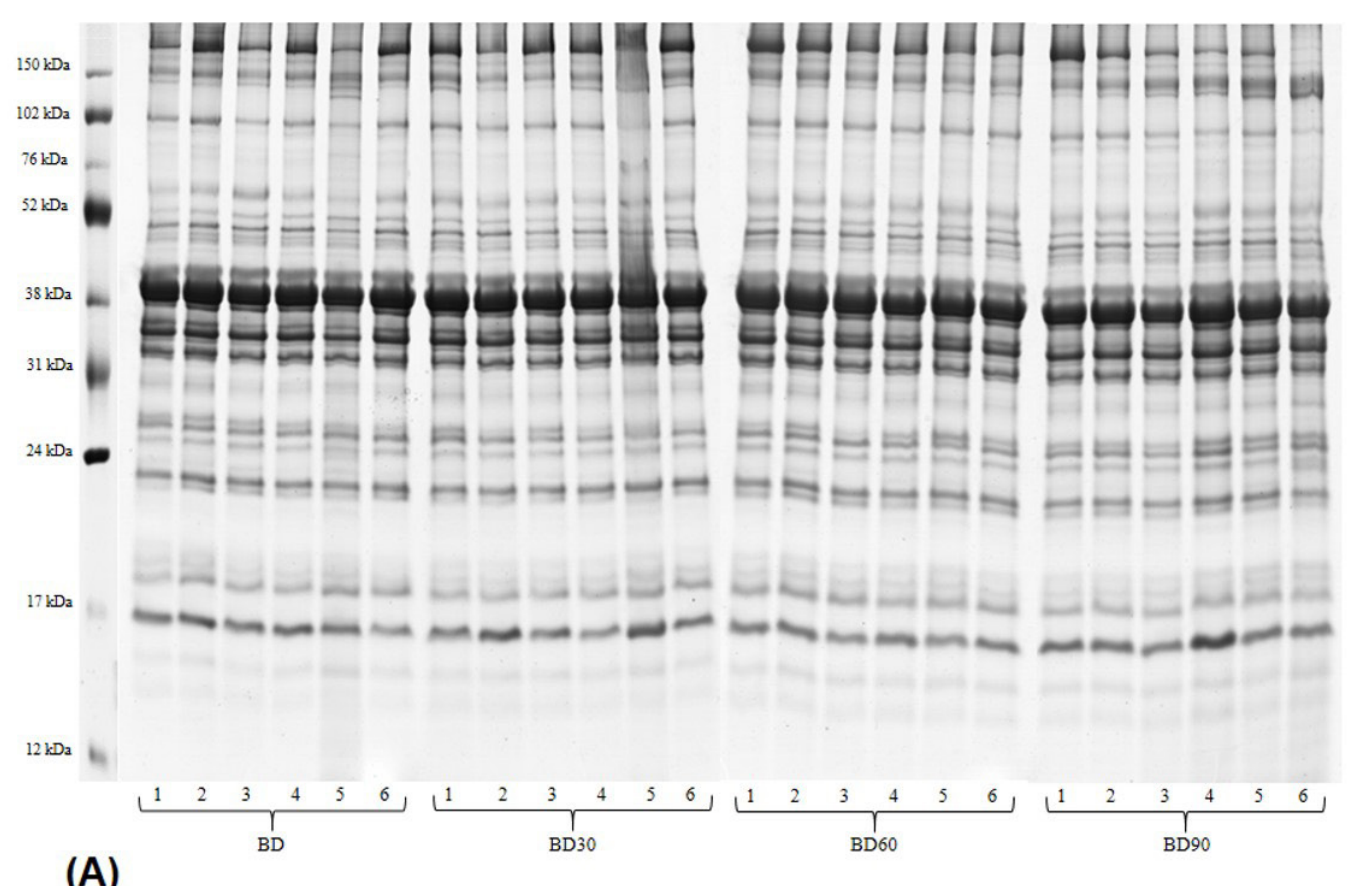

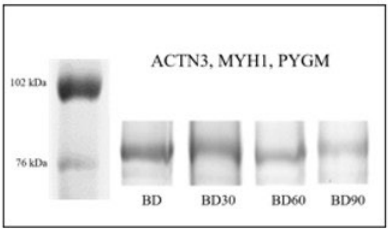

(B)

Figure 1. Figure 1A shows the electrophoresis gels bands intensity of SDS-PAGE 1D from nutritional groups (BD, BD30, BD60, BD90). The Figure $1 \mathrm{~B}$ shows the visual differences between groups in band 9, where the proteins Alpha-actin 3, Myosin 1 and Glycogen phosphorylase are present. The left lane corresponds to the molecular weight scale (225-12 kDa molecular weight standard mix).
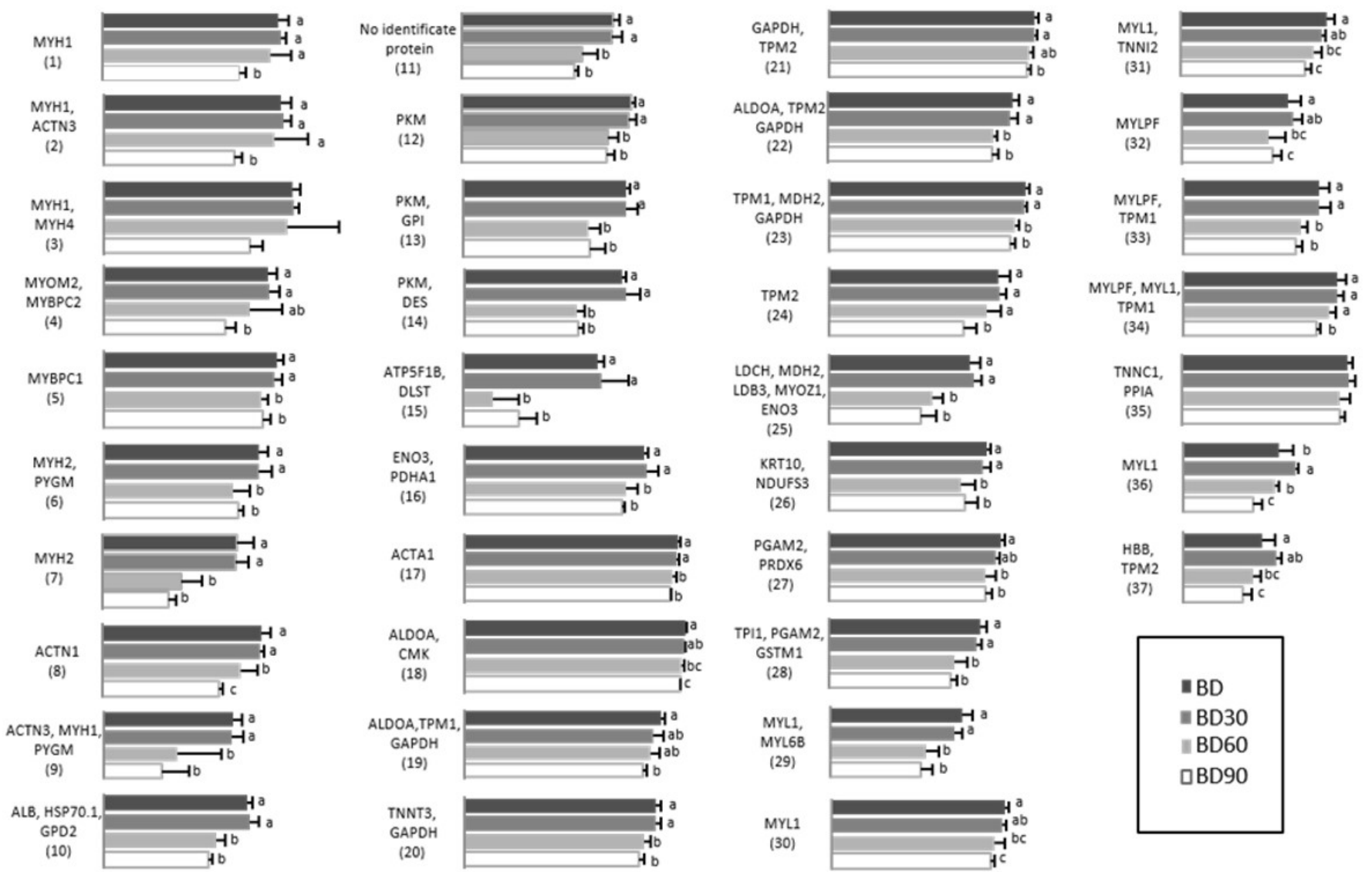

Figure 2. Comparison between proteins identified in longissimus lumborum from adult goats fed during 28 days with distinct nutritional levels (BD, $\mathrm{BD} 30, \mathrm{BD} 60, \mathrm{BD} 90)$. In parentheses, the number of the band obtained in the 1D SDS-PAGE is indicated. Values are expressed as means \pm SEM. Means with different letters differ $(\mathrm{p}<0.05)$. 


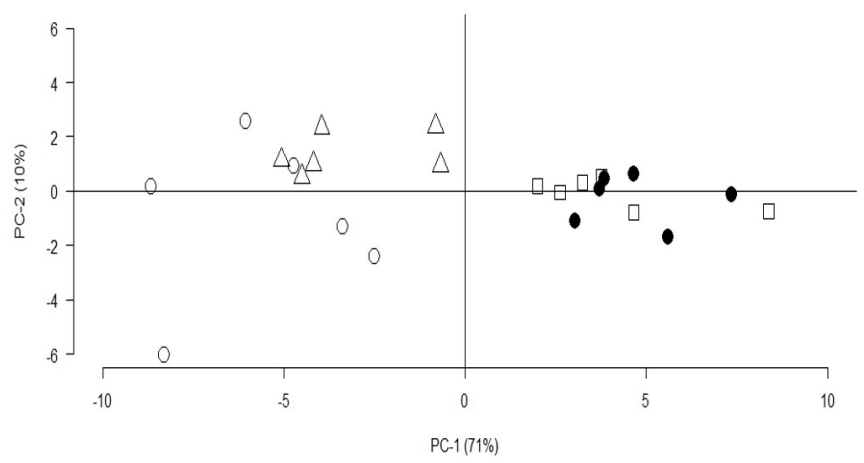

Figure 3. Score plot colored of the first (PC-1) and second (PC-2) principal components of multivariate analysis and value of each variance retained (PC-Var.) according to the proteins identified from longissimus lumborum of adult goats nutritional groups. The nutritional groups in the figure were: BD (Solid circle), BD30 (Empty square), BD60 (Empty circle) and BD90 (Empty triangle). Each symbol in the figure represents an individual goat analyzed.

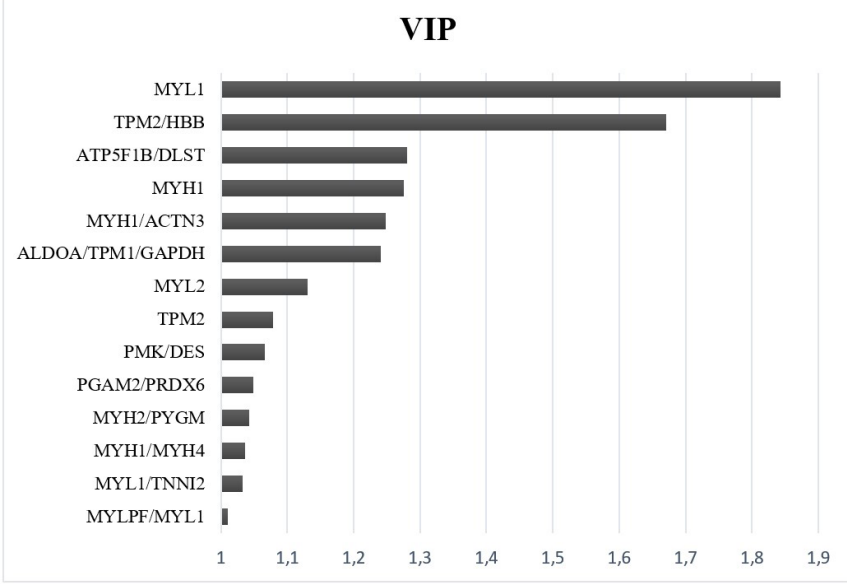

Figure 4. Protein bands with Variable of importance (VIP) value $>1.0$ in the PLS-DA multivariate model.

\section{Discussion}

In adult ruminants destined for slaughter, nutritional strategies for the finishing phase are usually aimed at gains in weight and conformation, mainly through adipose tissue deposition in the carcass. One of the consequences of increasing the energy density of diets is the marked hepatic accumulation of glycogen, the main substrate for lipogenesis. In the present study, the diets exceeding the nutritional requirements for maintenance stimulated an increase in feed intake, body weight and the weight of organs such as liver and pancreas, proven to be active in animal metabolism (Meyer et al., 2015). In goats, Mushi et al. (2009) also reported an increase in liver weight and glycogen concentration in goats receiving high levels of dietary supplements. Regarding this last phenomenon, some authors (Goetsch et al., 2011) suggest that a compensatory growth of this organ may occur to meet the new metabolic demands of the animal.
According to the maturity stage of the experimental animals, the diets did not induce changes in carcass lean mass or loin tissue and chemical composition. As expected, weight gain was mainly directed towards increased visceral adipose mass. In fact, in goats, as in other ruminant species, the growth rate reaches a limiting point in maturity at which the deposition of adipose tissue exceeds that of other tissues (Irshad et al., 2013). This usually occurs due to adipocyte hypertrophy with triglycerides, which are generated from the degradation of dietary carbohydrates and drained into the tissues by the portal hepatic system (Cianzio et al., 1985). In goats, adipose tissue deposition is late and directed towards accumulation of omental fat in the abdominal cavity, in contrast to discrete intramuscular deposition (Webb, 2014). For this reason, goat carcasses are characterized as lean meat, with more favorable nutritional aspects.

Increasing the nutritional level of the diets also significantly reduced the PUFA content of the loin intramuscular adipose tissue. This phenomenon was offset by the corresponding increase in SFA content (more evidently in groups BD60 and BD90), which in turn altered the PUFA/SFA ratio. The change in intramuscular fatty acid profile is related to alterations in the activity of the lipid metabolism enzymes fatty acid synthase (FAS), acetyl-CoA-carboxylase $\alpha$ (ACCa), involved in the synthesis of SFA, and stearoyl-CoA desaturase (SCD), which have desaturase action on SFA to convert them into MUFA (Smith et al., 2009).

The changes induced by supplementing the feed with high levels of non-fibrous carbohydrates alter the rumen dynamics by reducing the $\mathrm{pH}$, which can compromise the lipolytic processes in the rumen, interfering with the synthesis of fatty acids performed by microorganisms (Liu et al., 2019). As a result, the SFA content of the longissimus dorsi muscle of sheep increases, as described by Liu et al. (2019). Studies suggest that the activity of these enzymes is sensitive to changes in dietary availability, with a negative regulation of FAS, ACCa and SCD occurring under feed deprivation, in sheep (El-Sayed et al., 2019); and to increasing intramuscular fat levels, in cattle. Researchers have reported a positive regulation of FAS and ACCa that resulted in increased SFA contents (Ward et al., 2010).

A general analysis of the obtained results reveals a segmentation of the applied dietary treatments, with a clear approximation between the responses of groups $\mathrm{BD}$ and $\mathrm{BD} 30$, as opposed BD60 and BD90. This behavior was also observed by Safari et al. (2009) in goats supplemented with increasing levels of concentrated feed. In their study, the chemical and physical parameters of the carcass showed similarity between treatments with $0 \%$ and $33 \%$ as well as the groups that received over $60 \%$ of concentrate supplementation.

Indeed, the distinct responses between the diet groups were evident in the results pertaining to the muscular protein profile of longissimus lumborum muscle, which showed a generalized reduction in protein expression in the BD60 and BD90 groups. This suggests that increased nutritional intake by adult animals may change the muscle protein level, possibly as a consequence of changes in intracellular gene modulation (Baik et al., 2017).

In adult ruminants, the increase in lean mass provided by increased feed availability is not effective, since the flow of excess 

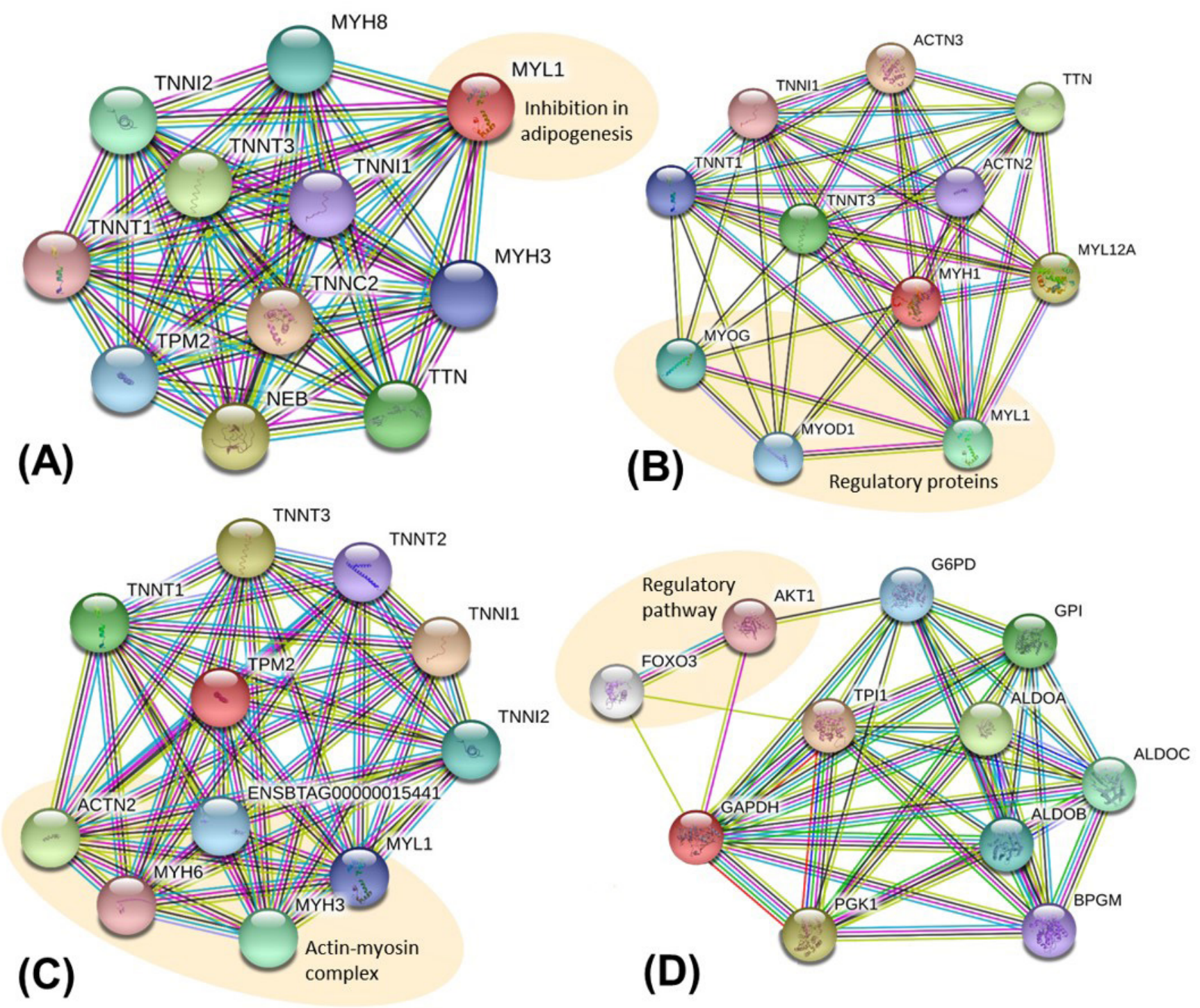

Figure 5. In-silico interaction analysis of proteins set with VIP $>1$ obtained from multivariate model. Proteins were analyzed with the web-based STRING software. Interaction search was set at "medium" confidence. Analyzed proteins were as follows: MYL1 (A), MYH1 (B), TPM2 (C), GAPDH (D), Green: textming; black: coexpression; blue: databases; and pink: experiments.

nutrients is directed towards lipid conversion. Adipose tissue accumulation in adult animals can act as a signal for a decrease in protein deposition in muscle tissue (Brameld et al., 2003).

The existing regulatory mechanism in postnatal cell growth is mainly through the action of myostatin in adult muscle tissue, which prompts a negative regulation in the gene expression of the main structural proteins that make up the muscle, namely, the heavy chain of myosin, troponin I and desmin (Durieux et al., 2007). On the other hand, intracellular lipid accumulation is known to be detected by the endoplasmic reticulum (ER), which leads to accumulation of unfolded proteins in the lumen of the organelle, causing a phenomenon called lipotoxicity (Mandl et al., 2009), characterized by an excess of SFA. As a result, lipid storage in non-adipose cells is increased, leading to changes in the expression pattern of genes related to ER stress as well as pro and anti-apoptotic pathways (Bax, BCL-2) and protein stability, including heat-shock proteins (HSP). In mice, Deldicque et al. (2010) demonstrated in myogenic cells that the negative regulation of protein synthesis in skeletal muscle tissue occurs due to ER stress, which is in turn induced by increased energy levels in the diet. Thus, changes in HSP70 expression have been associated with increased aggregation of unfolded enzymes (Sugimoto et al., 2003), with HSP70 being a chaperone related to the effectors of the pathway in the inactivated state (Deldicque et al., 2012).

Changes in the expression of the muscle protein profile may interfere with quality parameters, making it necessary to analyze reference regions of the skeletal muscle structure of the carcass 
such as the longissimus thoracis et lumborum muscle (Silva et al., 2007). Thus, the study of the protein profile provides information about the molecular events of transformation of muscle into meat, which function as quality biomarkers (Paredi et al., 2012) that can be used as predictive indices of sensory quality (Zuo et al., 2016).

At the molecular level, the relationship between fat deposition, mRNA expression and proteomic study in skeletal muscle shows that ruminants with high fat deposition rates have a significant decrease in the expression of MYL3 (Zhang et al., 2010). In our study, mass spectrometry identified the MYL1 protein in band 36, this protein band was what most contributed to the VIP values of the multivariate model for the separation between dietary treatments. It is known that this protein may have regulatory function in the myosin chains (Heissler \& Sellers, 2014), and the inhibition of its expression during adipogenesis results in negative regulation of the other myosins, as demonstrated in previous studies, suggesting that myofibrillar proteins are inhibited during adipogenesis (Singh et al., 2007). In its network of in silico interactions, MYL1 exhibits co-expression interactions with all proteins, including TPM2, present in the band placed in the VIP score.

Such myofibrillar proteins are composed of the myosin family, comprised of two heavy chains and four light chains, as well as actins, troponins and tropomyosins, forming the contractile structure of the muscle (Bouley et al., 2004). Based on information from the analysis of interactions in silico, we can confirm that these proteins have strong functional associations with each other, suggesting that changes in expression may cause generalized alterations in this protein group.

Using spectrometry, we identified the most abundant proteins that make up the goat muscle (Wang et al., 2016), e.g. those with glycolytic (PMK and ALDOA), transport (HBB) and stress (HSP70) functions, and almost $50 \%$ of contractile proteins, including ACT, TNNT, TNNI, TPM, DES, MYL, MYHC and, notably, myosin isoforms that characterize the adult muscle (Murphy et al., 2016).

It is noteworthy that protein expression does not occur in isolation, thus the molecular regulation between the glucose metabolism and skeletal muscle development is associated with events that occurred in the animal muscle (Hocquette et al., 1998). Therefore, a correlation between energy metabolism proteins found in the VIP score may be achieved through changes at expression and co-expression levels. In our findings, the band 15 which was third in VIP value, identifying DLST and $\mathrm{ATP} 5 \mathrm{~F} 1 \mathrm{~B}$ proteins in this band, which participate directly in the Krebs cycle inside the mitochondria, with DLST being responsible for converting 2-oxoglutarate into succinyl-CoA, which then forms succinate, ATP and CoA (Schmid et al., 2004). A reduction in the pattern of protein sub-expression in response to the increment of dietetic levels was verified in the referred band, being likely to consider that there was modification in mitochondrial regulation and glucose gathering in high energy diets. Previous studies sustain that high energy diets may promote damage to mitochondrial function, showing reduced levels of intracellular ATP, which triggers a significant reduction of the myosin heavy chains (MYHC) expression, in addition to exhibit activation of stress factors in the ER and increment of skeletal muscle apoptosis (Yuzefovych et al., 2013).

Furthermore in cattle, increased fat deposition in the muscle induces an underexpression of mRNA of the d-subunit of ATP (Zhang et al., 2010), which in turn may be associated with a gradual decrease in the rate of energy consumption in the muscle (Wang et al., 2009). Related to the energy-metabolism, the presence of GAPDH was identified in bands 19 to 23, associated with several proteins linked to the processes of intracellular energy production and muscle contraction, such in band 19 where ALDOA proteins were identified, involved in the synthesis of D-glyceraldehyde 3-phosphate and glycerone phosphate from D-glucose and TPM1 involved in calciumdependent regulation of striated muscle contraction (Kim \& Dang, 2005). In addition, the protein MDH2, identified in band 23 along with the protein GAPDH, is part of the tricarboxylic acid cycle in the mitochondrial matrix and; for all bands where these proteins involved in the energy metabolism were detected there was a reduction of protein expression in the animal groups which received higher levels of energy (Seidler, 2013).

In the network of interactions in silico, we observed that GAPDH associates with protein AKT1 kinase, which acts in regulatory process of myostatin. The regulation of myostatin may also respond to the events of energy metabolism, through the inhibition of AKT1, which possess the function of regulating glucose uptake (Egerman \& Glass, 2014), which may result in the induction of muscular atrophy by blocking of the protein synthesis pathaway mediated by negative regulation of AKT levels (Sharma et al., 2015).

Among the molecular aspects of meat quality, tenderness is related to the degree of post mortem proteolysis of the myofibrillar structure (actin-myosin-troponin interactions), whose integrity interferes with the post mortem meat tenderization process (Kim et al., 2008). The process of conversion of muscle to meat begins with apoptosis, since it involves energy expenditure and the action of HSP proteins (Ouali et al., 2006), in two main pathways: the intrinsic mitochondrial pathway and the ER stress pathway (Chen et al., 2020), which are responsible for the oxidative stress that promotes meat tenderness and the response of HSPB1 and HSPB6, respectively (D’Alessandro et al., 2012).

Differential expression of myofibrillar proteins such as MYH (bands 1-3, 6, 7 and 9), ACTN (bands 3, 8 and 9), TPM (bands $19,21-24,33,34$ and 37), DES (band 14), as well as glycolytic proteins, for example LDH (band 25), ENO3 (bands 16 and 25), TPI (band 28) and GAPDH (bands 19-23) have been described as biomarkers of quality prediction meat. According to Lana \& Zolla (2016) the abundance of proteins and/or factors are correlated to the stimulation of increase in resistance in meat, as high levels of actin; increased phosphorylation of the actin fragments (characterized as a marker of apoptotic resistance); high levels of tropomyosin 1; and high desmin content of meat with a low $\mathrm{pH}$ value. Some authors showed protein biomarkers related to meat tenderness, through the association between lower abundance of myosin heavy chain (MYHC), lactate dehydrogenase chain $\mathrm{B}$ (LDHB) and higher abundance of ENO3 associated with high tenderness scores in bovine's longissimus thoracis muscle (Picard et al., 2014). 
It is known that ENO3 converts glucose to pyruvate, GADPH synthesizes pyruvate from D-glyceraldehyde 3-phosphate and TPI controls the glycerol content through the reversible conversion of glyceraldehydes-3-phosphate. The expression of these energymetabolism proteins in the identified bands, can be considered a useful tool in the prediction of meat quality, as research shows that the expression of TPI and ENO3 in the muscle decreases as the amount of fat increases in cattle (Kim et al., 2009).

Glycolytic proteins are strongly linked to meat quality, as they regulate its $\mathrm{pH}$. The muscle-to-meat transformation process is usually accompanied by a decline in $\mathrm{pH}$, which in turn is associated with softness and color (Page et al., 2001). The lactate dehydrogenase protein identified is responsible for catalyzing the conversion of L-lactate and NAD+ into pyruvate and NADH in the final stage of anaerobic glycolysis, and the increase in LDHA after slaughter correlates with the decrease in $\mathrm{pH}$, revealing an inversely proportional relationship between protein expression and $\mathrm{pH}$ (Polati et al., 2012). $\mathrm{pH}$ values above 5.8 induce protein denaturation, causing the myofibrils to shrink (Cassar-Malek et al., 2007). Several authors have demonstrated how the $\mathrm{pH}$ decrease in meat can be associated with high values of ENO 3, LDH-B, myosin binding protein $\mathrm{H}$-like (MyBP-H) and Hsp70 (Gagaoua et al., 2015). Glycolytic enzymes have their expression increased by a faster energy metabolism, resulting in a faster $\mathrm{pH}$ decline in the meat product (Cassar-Malek \& Picard, 2016).

\section{Conclusions}

In summary, the increase of nutritional balance in finish diets was able to stimulate the alimentary intake but have been shown to promote a body gain mainly by deposit of visceral fat in adult goats.

There were no evidences that finish diets support a quality enhance of tissue structure and chemical composition of loin, but high diet levels show to have a negative effect on fatty acid profile of the loin by increasing of saturated portion of intramuscular fat.

At the same time, we demonstrated that nutritional supply induced a sub-expression of proteins of muscle. Some of these proteins are glycolytic and structural function and participate of important metabolic events in the transformation of muscle into meat, which significantly effort on meat quality traits.

Finally we can conclude that in the our experimental conditions the increase of level in diets for finishing in adult goats did not produce positive effects on animal conformation but it profoundly modifies the expression of fundamental proteins for attributing the qualitative aspects of the meat product. For this reason, a careful definition of the best feeding plan for goats destined for finishing should be carefully considered and studied in the future.

\section{Acknowledgements}

This work was supported by grant Proex grant No. 23038.002808/2017-56 funded by Capes $\backslash$ Brazil. Marques I.T.O. was the recipient of a scholarship from Funcap/Brazil. Vasconcelos F.R. was the recipient of a scholarship from Funcap/CNPq/
Brazil. Moura A.A. and Rondina D. are senior investigators of $\mathrm{CNPq} /$ Brazil.

\section{References}

Aguayo-Ulloa, L. A., Miranda-de la Lama, G. C., Pascual-Alonso, M., Fuchs, K., Olleta, J. L., Campo, M. M., Alierta, S., Villarroel, M., \& María, G. A. (2013). Effect of feeding regime during finishing on lamb welfare, production performance and meat quality. Small Ruminant Research, 111(1-3), 147-156. http://dx.doi.org/10.1016/j. smallrumres.2012.09.011.

Assan, N. (2015). Some factors influencing dressing percentage in goat meat production. Scientific Journal of Review, 4(10), 156-164.

Association of Official Analytical Chemists - AOAC (1990). Official methods of analysis. Arlington: The Association.

Baik, M., Kang, H. J., Park, S. J., Na, S. W., Piao, M., Kim, S. Y., Fassah, D. M., \& Moon, Y. S. (2017). Triennial growth and development symposium: molecular mechanisms related to bovine intramuscular fat deposition in the longissimus muscle. Journal of Animal Science, 95(5), 2284-2303. http://dx.doi.org/10.2527/jas2016.1160. PMid:28727015.

Bjarnadóttir, S. G., Hollung, K., Færgestad, E. M., \& Veiseth-Kent, E. (2010). Proteome changes in bovine longissimus thoracis muscle during the first $48 \mathrm{~h}$ postmortem: shifts in energy status and myofibrillar stability. Journal of Agricultural and Food Chemistry, 58(12), 74087414. http://dx.doi.org/10.1021/jf100697h. PMid:20515034.

Bouley, J., Chambon, C., \& Picard, B. (2004). Mapping of bovine skeletal muscle proteins using two-dimensional gel electrophoresis and mass spectrometry. Proteomics, 4(6), 1811-1824. http://dx.doi. org/10.1002/pmic.200300688. PMid:15174147.

Bradford, M. M. (1976). A rapid and sensitive method for the quantitation of microgram quantities of protein utilizing the principle of proteindye binding. Analytical Biochemistry, 72(1-2), 248-254. http://dx.doi. org/10.1016/0003-2697(76)90527-3. PMid:942051.

Brameld, J. M., Fahey, A. J., Langley-Evans, S. C., \& Buttery, P. J. (2003). Nutritional and hormonal control of muscle growth and fat deposition. Archiv fur Tierzucht, 46, 143-156.

Brasil. Presidência da República. Casa Civil. (1952). Decreto no 30.691, de 29 de março de 1952. Aprova o novo Regulamento da Inspeção Industrial e Sanitária de Produtos de Origem Animal. Diário Oficial [da] União. Brasília.

Cassar-Malek, I., \& Picard, B. (2016). Expression marker-based strategy to improve beef quality. The Scientific World Journal, 2016, 2185323. http://dx.doi.org/10.1155/2016/2185323. PMid:27066527.

Cassar-Malek, I., Passelaigue, F., Bernard, C., Léger, J., \& Hocquette, J. (2007). Target genes of myostatin loss-of-function in muscles of late bovine fetuses. BMC Genomics, 8(1), 63. http://dx.doi. org/10.1186/1471-2164-8-63. PMid:17331240.

Chen, C., Zhang, J., Guo, Z., Shi, X., Zhang, Y., Zhang, L., Yu, Q., \& Han, L. (2020). Effect of oxidative stress on AIF-mediated apoptosis and bovine muscle tenderness during postmortem aging. Journal of Food Science, 85(1), 77-85. http://dx.doi.org/10.1111/1750-3841.14969. PMid:31816098.

Cianzio, D. S., Topel, D. G., Whitehurst, G. B., Beitz, D. C., \& Self, H. L. (1985). Adipose tissue growth and cellularity: changes in bovine adipocyte size and number. Journal of Animal Science, 60(4), 970976. http://dx.doi.org/10.2527/jas1985.604970x. PMid:3988658.

D’Alessandro, A., Marrocco, C., Rinalducci, S., Mirasole, C., Failla, S., \& Zolla, L. (2012). Chianina beef tenderness investigated through integrated Omics. Journal of Proteomics, 75(14), 4381-4398. http:// dx.doi.org/10.1016/j.jprot.2012.03.052. PMid:22510581.

De Lazari, F. L., Sontag, E. R., Schneider, A., Moura, A. A. A., Vasconcelos, F. R., Nagano, C. S., Mattos, R. C., Jobim, M. I. M., \& BustamanteFilho, I. C. (2019). Seminal plasma proteins and their relationship 
with sperm motility and morphology in boars. Andrologia, 51(4), e13222. http://dx.doi.org/10.1111/and.13222. PMid:30592081.

Deldicque, L., Cani, P. D., Philp, A., Raymackers, J. M., Meakin, P. J., Ashford, M. L. J., Delzenne, N. M., Francaux, M., \& Baar, K. (2010). The unfolded protein response is activated in skeletal muscle by highfat feeding: Potential role in the downregulation of protein synthesis. American Journal of Physiology. Endocrinology and Metabolism, 299(5), E695-E705. http://dx.doi.org/10.1152/ajpendo.00038.2010. PMid:20501874.

Deldicque, L., Hespel, P., \& Francaux, M. (2012). Endoplasmic reticulum stress in skeletal muscle: Origin and metabolic consequences. Exercise and Sport Sciences Reviews, 40(1), 43-49. http://dx.doi.org/10.1097/ JES.0b013e3182355e8c. PMid:21918459.

Durieux, A.-C., Amirouche, A., Banzet, S., Koulmann, N., Bonnefoy, R., Pasdeloup, M., Mouret, C., Bigard, X., Peinnequin, A., \& Freyssenet, D. (2007). Ectopic expression of myostatin induces atrophy of adult skeletal muscle by decreasing muscle gene expression. Endocrinology, 148(7), 3140-3147. http://dx.doi.org/10.1210/en.2006-1500. PMid:17395701.

Egerman, M. A., \& Glass, D. J. (2014). Signaling pathways controlling skeletal muscle mass. Critical Reviews in Biochemistry and Molecular Biology, 49(1), 59-68. http://dx.doi.org/10.3109/10409238.2013.85 7291. PMid:24237131.

El-Sayed, A., Ateya, A., Hamed, M., Shoieb, S., Ibrahim, H., El-ashker, M., Youssef, M., \& Ibrahim, F. (2019). Gene expression pattern of acetyl-coA carboxylase alpha, fatty acid synthase, and stearoyl-CoA desaturase in pregnant Barki sheep under complete feed deprivation. Mansoura Veterinary Medical Journal, 20(3), 8-13. http://dx.doi. org/10.35943/mvmj.2019.23.202.

Fernandes, C. C. L., Aguiar, L. H., Calderón, C. E. M., Silva, A. M., Alves, J. P. M., Rossetto, R., Bertolini, L. R., Bertolini, M., \& Rondina, D. (2018a). Nutritional impact on gene expression and competence of oocytes used to support embryo development and livebirth by cloning procedures in goats. Animal Reproduction Science, 188, 1-12. http://dx.doi.org/10.1016/j.anireprosci.2017.10.012. PMid:29233618.

Fernandes, C. C. L., Rodriguez-Villamil, P., Vasconcelos, F. R., Nagano, C. S., Rossetto, R., Moura, A. A. A. N., \& Rondina, D. (2018b). Proteome of the periovulatory oviduct and uterus of goats as related to nutritional balance. Reproduction in Domestic Animals, 53(5), 1085-1095. http://dx.doi.org/10.1111/rda.13208. PMid:29885005.

Folch, J., Lees, M., \& Stanley, G. H. S. (1957). A simple method for the isolation and purification of total lipides from animal tissues. The Journal of Biological Chemistry, 226(1), 497-509. http://dx.doi. org/10.1016/S0021-9258(18)64849-5. PMid:13428781.

Food and Agriculture Organization - FAO. (2019). Meat market review. Retrieved from http://www.fao.org/3/ca3880en/ca3880en.pdf

Food and Agriculture Organization - FAO. (2020). FAOSTAT: production live animals. Retrieved from http://faostat3.fao.org/download/Q/QA/E.

Fruet, A. P. B., Stefanello, F. S., Rosado, A. G. Jr., Souza, A. N. M., Tonetto, C. J., \& Nörnberg, J. L. (2016). Whole grains in the finishing of culled ewes in pasture or feedlot: performance, carcass characteristics and meat quality. Meat Science, 113, 97-103. http://dx.doi.org/10.1016/j. meatsci.2015.11.018. PMid:26638020.

Gagaoua, M., Terlouw, E. M. C., Micol, D., Boudjellal, A., Hocquette, J.-F., \& Picard, B. (2015). Understanding early post-mortem biochemical processes underlying meat color and $\mathrm{pH}$ decline in the longissimus thoracis muscle of young blond d'aquitaine bulls using protein biomarkers. Journal of Agricultural and Food Chemistry, 63(30), 67996809. http://dx.doi.org/10.1021/acs.jafc.5b02615. PMid:26160326.

Goetsch, A. L., Merkel, R. C., \& Gipson, T. A. (2011). Factors affecting goat meat production and quality. Small Ruminant Research, 101(1-3), 173-181. http://dx.doi.org/10.1016/j.smallrumres.2011.09.037.
Gosselin, R., Rodrigue, D., \& Duchesne, C. (2010). A Bootstrap-VIP approach for selecting wavelength intervals in spectral imaging applications. Chemometrics and Intelligent Laboratory Systems, 100(1), 12-21. http://dx.doi.org/10.1016/j.chemolab.2009.09.005.

Hartman, L., \& Lago, R. C. (1973). Rapid preparation of fatty acid methyl esters from lipids. Laboratory Practice, 22(6), 475-476, passim. PMid:4727126.

Heissler, S. M., \& Sellers, J. R. (2014). Myosin light chains: teaching old dogs new tricks. Bioarchitecture, 4(6), 169-188. http://dx.doi.org/1 0.1080/19490992.2015.1054092. PMid:26155737.

Hocquette, J. F., Ortigues-Marty, I., Pethick, D., Herpin, P., \& Fernandez, X. (1998). Nutritional and hormonal regulation of energy metabolism in skeletal muscles of meat-producing animals. Livestock Production Science, 56(2), 115-143. http://dx.doi.org/10.1016/S0301-6226(98)00187-0.

Irshad, A., Kandeepan, G., Kumar, S., Ashish, K. A., Vishnuraj, M. R., \& Shukla, V. (2013). Factors influencing carcass composition of livestock: a review. Journal of Animal Production Advances, 3(5), 177-186. http://dx.doi.org/10.5455/japa.20130531093231.

Kim, J., \& Dang, C. V. (2005). Multifaceted roles of glycolytic enzymes. Trends in Biochemical Sciences, 30(3), 142-150. http://dx.doi. org/10.1016/j.tibs.2005.01.005. PMid:15752986.

Kim, N. K., Cho, S., Lee, S. H., Park, H. R., Lee, C. S., Cho, Y. M., Choy, Y. H., Yoon, D., Im, S. K., \& Park, E. W. (2008). Proteins in longissimus muscle of Korean native cattle and their relationship to meat quality. Meat Science, 80(4), 1068-1073. http://dx.doi. org/10.1016/j.meatsci.2008.04.027. PMid:22063838.

Kim, N., Lee, S., Cho, Y., Son, E., Kim, K., Lee, C., Yoon, D., Im, S., Oh, S., \& Park, E. (2009). Proteome analysis of the m. longissimus dorsi between fattening stages in Hanwoo steer. BMB Reports, 42(7), 433-438. http://dx.doi.org/10.5483/BMBRep.2009.42.7.433. PMid:19643041.

Lametsch, R., \& Bendixen, E. (2001). Proteome analysis applied to meat science: characterizing post mortem changes in porcine muscle. Journal of Agricultural and Food Chemistry, 49(10), 4531-4537. http://dx.doi.org/10.1021/jf010103g. PMid:11599984.

Lana, A., \& Zolla, L. (2016). Proteolysis in meat tenderization from the point of view of each single protein: a proteomic perspective. Journal of Proteomics, 147, 85-97. http://dx.doi.org/10.1016/j. jprot.2016.02.011. PMid:26899368.

Liu, Y., Lang, M., Zhen, Y., Chen, X., Sun, Z., Zhao, W., Zhang, X., Wang, T., \& Qin, G. (2019). Effects of yeast culture supplementation and the ratio of non-structural carbohydrate to fat on growth performance, carcass traits and the fatty acid profile of the longissimus dorsi muscle in lambs. Journal of Animal Physiology and Animal Nutrition, 103(5), 1274-1282. http://dx.doi.org/10.1111/jpn.13128. PMid:31149756.

Mandl, J., Mészáros, T., Bánhegyi, G., Hunyady, L., \& Csala, M. (2009). Endoplasmic reticulum: nutrient sensor in physiology and pathology. Trends in Endocrinology and Metabolism, 20(4), 194-201. http:// dx.doi.org/10.1016/j.tem.2009.01.003. PMid:19349192.

Meyer, A. M., Vraspir, R. A., Ellison, M. J., \& Cammack, K. M. (2015). The relationship of residual feed intake and visceral organ size in growing lambs fed a concentrate- or forage-based diet. Livestock Science, 176, 85-90. http://dx.doi.org/10.1016/j.livsci.2015.03.019.

Miller, M. F., Carr, M. A., Ramsey, C. B., Crockett, K. L., \& Hoover, L. C. (2001). Consumer thresholds for establishing the value of beef tenderness. Journal of Animal Science, 79(12), 3062-3068. http:// dx.doi.org/10.2527/2001.79123062x. PMid:11811460.

Murphy, S., Dowling, P., \& Ohlendieck, K. (2016). Comparative skeletal muscle proteomics using two-dimensional gel electrophoresis. Proteomes, 4(3), 27. http://dx.doi.org/10.3390/proteomes4030027. PMid:28248237.

Mushi, D. E., Safari, J., Mtenga, L. A., Kifaro, G. C., \& Eik, L. O. (2009). Growth and distribution of non-carcass components of Small East 
African and F1 Norwegian crossbred goats under concentrate diets. Livestock Science, 126(1-3), 80-86. http://dx.doi.org/10.1016/j. livsci.2009.06.001.

National Research Council - NRC. (2007). Nutrient requirements of small ruminants: sheep, goats, cervids, and new world camelids (6th ed.). Washington: National Academy Press.

Oliveira, C. H. A., Silva, A. M., Silva, L. M., Van Tilburg, M. F., Fernandes, C. C. L., Moura, A. A., Moreno, F. B. M. B., Monteiro-Moreira, A. C. O., Moreira, R. A., Bezerra, F. J., \& Rondina, D. (2015). Meat quality assessment from young goats fed for long periods with castor de-oiled cake. Meat Science, 106, 16-24. http://dx.doi.org/10.1016/j. meatsci.2015.03.008. PMid:25866931.

Ouali, A., Herrera-Mendez, C. H., Coulis, G., Becila, S., Boudjellal, A., Aubry, L., \& Sentandreu, M. A. (2006). Revisiting the conversion of muscle into meat and the underlying mechanisms. Meat Science, 74(1), 44-58. http://dx.doi.org/10.1016/j.meatsci.2006.05.010. PMid:22062715.

Page, J. K., Wulf, D. M., \& Schwotzer, T. R. (2001). A survey of beef muscle color and pH. Journal of Animal Science, 79(3), 678-687. http://dx.doi.org/10.2527/2001.793678x. PMid:11263828.

Paredi, G., Raboni, S., Bendixen, E., de Almeida, A. M., \& Mozzarelli, A. (2012). "Muscle to meat" molecular events and technological transformations: the proteomics insight. Journal of Proteomics, 75(14), 4275-4289. http://dx.doi.org/10.1016/j.jprot.2012.04.011. PMid:22543183.

Picard, B., Gagaoua, M., Micol, D., Cassar-Malek, I., Hocquette, J., \& Terlouw, C. E. M. (2014). Inverse relationships between biomarkers and beef tenderness according to contractile and metabolic properties of the muscle. Journal of Agricultural and Food Chemistry, 62(40), 9808-9818. http://dx.doi.org/10.1021/jf501528s. PMid:25175407.

Polati, R., Menini, M., Robotti, E., Millioni, R., Marengo, E., Novelli, E., Balzan, S., \& Cecconi, D. (2012). Proteomic changes involved in tenderization of bovine Longissimus dorsi muscle during prolonged ageing. Food Chemistry, 135(3), 2052-2069. http://dx.doi.org/10.1016/j. foodchem.2012.06.093. PMid:22953957.

R Core Team. (2018). R: A Language and Environment for Statistical Computing, version 3.5. 1. Retrieved from https://www.R-project. org. Vienna: R Foundation for Statistical Computing.

Safari, J., Mushi, D. E., Mtenga, L. A., Kifaro, G. C., \& Eik, L. O. (2009). Effects of concentrate supplementation on carcass and meat quality attributes of feedlot finished Small East African goats. Livestock Science, 125(2-3), 266-274. http://dx.doi.org/10.1016/j.livsci.2009.05.007.

Sanchez, J., Chiappe, D., Converset, V., Hoogland, C., Binz, P., Paesano, S., Appel, R. D., Wang, S., Sennitt, M., Nolan, A., Cawthorne, M. A., \& Hochstrasser, D. F. (2001). The mouse SWISS-2D PAGE database: a tool for proteomics study of diabetes and obesity. Proteomics, 1(1), 136-163. http://dx.doi.org/10.1002/1615-9861(200101)1:1<136::AIDPROT136>3.0.CO;2-1. PMid:11680894.

Schmid, G. M., Converset, V., Walter, N., Sennitt, M. V., Leung, K., Byers, H., Ward, M., Hochstrasser, D. F., Cawthorne, M. A., \& Sanchez, J. (2004). Effect of high-fat diet on the expression of proteins in muscle, adipose tissues, and liver of C57BL/6 mice. Proteomics, 4(8), 22702282. http://dx.doi.org/10.1002/pmic.200300810. PMid:15274121.

Seidler, N. W. (2013). GAPDH and intermediary metabolism. In GAPDH: biological properties and diversity (pp. 37-59). New York: Springer. http://dx.doi.org/10.1007/978-94-007-4716-6_2.

Sharma, M., McFarlane, C., Kambadur, R., Kukreti, H., Bonala, S., \& Srinivasan, S. (2015). Myostatin: expanding horizons. IUBMB Life, 67(8), 589-600. http://dx.doi.org/10.1002/iub.1392. PMid:26305594.

Silva, S. R., Guedes, C. M., Santos, V. A., Lourenço, A. L., Azevedo, J. M. T., \& Dias-da-Silva, A. (2007). Sheep carcass composition estimated from Longissimus thoracis et lumborum muscle volume measured by in vivo real-time ultrasonography. Meat Science, 76(4), 708-714. http://dx.doi.org/10.1016/j.meatsci.2007.02.009. PMid:22061248.

Singh, J., Verma, N. K., Kansagra, S. M., Kate, B. N., \& Dey, C. S. (2007). Altered PPAR $\gamma$ expression inhibits myogenic differentiation in C2C12 skeletal muscle cells. Molecular and Cellular Biochemistry, 294(1-2), 163-171. http://dx.doi.org/10.1007/s11010-006-9256-x. PMid:16838108.

Smith, S. B., Gill, C. A., Lunt, D. K., \& Brooks, M. A. (2009). Regulation of fat and fatty acid composition in beef cattle. Asian-Australasian Journal of Animal Sciences, 22(9), 1225-1233. http://dx.doi.org/10.5713/ ajas.2009.r.10

Sousa-Victor, P., García-Prat, L., Serrano, A. L., Perdiguero, E., \& Muñoz-Cánoves, P. (2015). Muscle stem cell aging: regulation and rejuvenation. Trends in Endocrinology and Metabolism, 26(6), 287296. http://dx.doi.org/10.1016/j.tem.2015.03.006. PMid:25869211.

Sugimoto, M., Furuoka, H., \& Sugimoto, Y. (2003). Deletion of one of the duplicated Hsp70 genes causes hereditary myopathy of diaphragmatic muscles in Holstein-Friesian cattle. Animal Genetics, 34(3), 191-197. http://dx.doi.org/10.1046/j.1365-2052.2003.00990.x. PMid:12755819.

Wang, Y. H., Bower, N. I., Reverter, A., Tan, S. H., De Jager, N., Wang, R., McWilliam, S. M., Cafe, L. M., Greenwood, P. L., \& Lehnert, S. A. (2009). Gene expression patterns during intramuscular fat development in cattle. Journal of Animal Science, 87(1), 119-130. http://dx.doi.org/10.2527/jas.2008-1082. PMid:18820161.

Wang, Z., He, F., Rao, W., Ni, N., Shen, Q., \& Zhang, D. (2016). Proteomic analysis of goat Longissimus dorsi muscles with different drip loss values related to meat quality traits. Food Science and Biotechnology, 25(2), 425-431. http://dx.doi.org/10.1007/s10068-016-0058-y. PMid:30263286.

Ward, R. E., Woodward, B., Otter, N., \& Doran, O. (2010). Relationship between the expression of key lipogenic enzymes, fatty acid composition, and intramuscular fat content of Limousin and Aberdeen Angus cattle. Livestock Science, 127(1), 22-29. http://dx.doi.org/10.1016/j. livsci.2009.09.005.

Webb, E. C. (2014). Goat meat production, composition, and quality. Animal Frontiers, 4(4), 33-37. http://dx.doi.org/10.2527/af.2014-0031.

Xu, C., Bailly-Maitre, B., \& Reed, J. C. (2005). Endoplasmic reticulum stress: cell life and death decisions. The Journal of Clinical Investigation, 115(10), 2656-2664. http://dx.doi.org/10.1172/JCI26373. PMid:16200199.

Yuzefovych, L. V., Musiyenko, S. I., Wilson, G. L., \& Rachek, L. I. (2013). Mitochondrial DNA damage and dysfunction, and oxidative stress are associated with endoplasmic reticulum stress, protein degradation and apoptosis in high fat diet-induced insulin resistance mice. PLoS One, 8(1), e54059. http://dx.doi.org/10.1371/journal.pone.0054059. PMid:23342074.

Zapata, I., Zerby, H. N., \& Wick, M. (2009). Functional proteomic analysis predicts beef tenderness and the tenderness differential. Journal of Agricultural and Food Chemistry, 57(11), 4956-4963. http://dx.doi.org/10.1021/jf900041j. PMid:19449808.

Zhang, Q., Lee, H. G., Han, J. A., Kim, E. B., Kang, S. K., Yin, J., Baik, M., Shen, Y., Kim, S. H., Seo, K. S., \& Choi, Y. J. (2010). Differentially expressed proteins during fat accumulation in bovine skeletal muscle. Meat Science, 86(3), 814-820. http://dx.doi.org/10.1016/j. meatsci.2010.07.002. PMid:20667664.

Zuo, H., Han, L., Yu, Q., Niu, K., Zhao, S., \& Shi, H. (2016). Proteome changes on water-holding capacity of yak longissimus lumborum during postmortem aging. Meat Science, 121, 409-419. http://dx.doi. org/10.1016/j.meatsci.2016.07.010. PMid:27448195. 